Año LI. urtea

$128-2019$

Uztaila-abendua Julio-diciembre

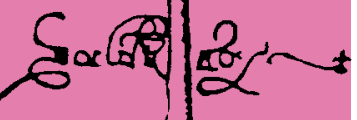

the

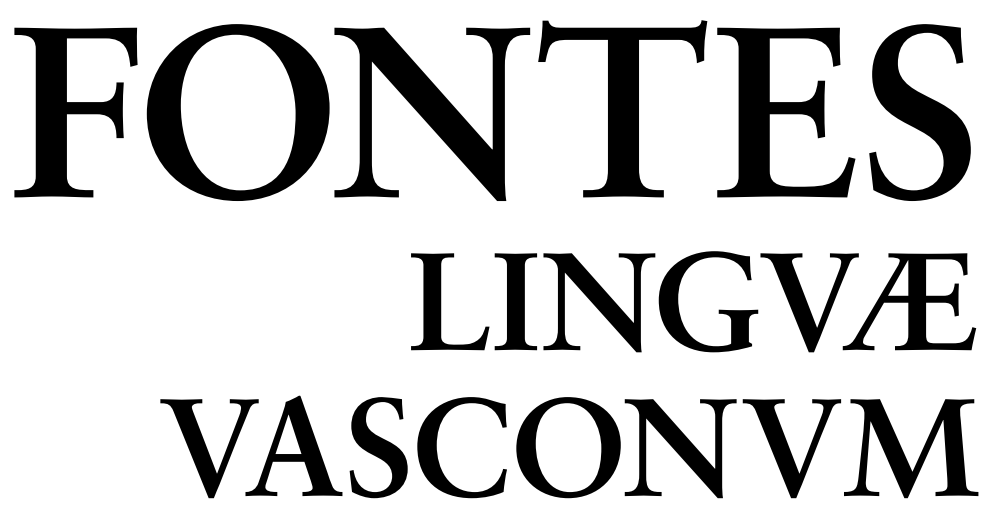

STVDIA ET DOCVMENTA
SEPARATA

\section{Bizkai sartaldeko agiri judizial bat euskaraz: Zolloko galdetegia (1770)}

Eneko Zuloaga San Román, José Alfonso Antequera Chávez

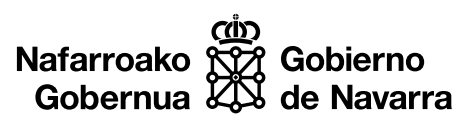

0000 


\title{
Bizkai sartaldeko agiri judizial bat euskaraz: Zolloko galdetegia (1770)
}

Un nuevo documento judicial en euskera vizcaíno occidental: el cuestionario de Zollo (1770)

A new judicial document from Western Biscay: the Zollo questionnaire (1770)

\author{
Eneko ZuLOAGA SAN Román \\ Euskal Herriko Unibertsitatea (UPV/EHU) \\ eneko.zuloaga@ehu.eus \\ José Alfonso ANTEQuera CHÁveZ \\ Eusko Ikaskuntza (EI), Zatak Herri Ondarea Ikerketa Elkartea \\ josealfonso.antequera@gmail.com
}

\begin{abstract}
Lan honek MINECOk finantzatutako «Monumenta Linguae Vasconum (V): cronología y periodización» (kodea: FFI2016-75032-P) ikerketa-proiektuaren eta Eusko Jaurlaritzaren «Historia de la lengua vasca y lingüística histórico-comparada» (HMLV-LHC) [IT1344-19] ikerketa-talde kontsolidatuaren babesa izan du.

Lehenik eta behin, bihoazkio gure eskerrik zintzoenak Ander Ros Cubas ikertzaileari, testu honen edizioa eta iruzkina gure esku utziaz eta argitaratzeko adorea emanaz hain eskuzabal jokatzeagatik. Bigarrenik, eskerrik asko Bizkaiko Probintziako Agiritegi Historikoko (BPAH) zuzendari Pilar Rodríguez Plaza andreari, hainbat eskuizkribu ikusteko eta erabiltzeko emandako erraztasunengatik.

Halaber, eskerrik asko testuko zenbait zalantza argitzen lagundu digutenei: Borja Ariztimuño, Dorota Krajewska eta Ekaitz Santaziliari.
\end{abstract}

Jasotze data: 2019/02/25. Behin-behineko onartze data: 2019/05/29. Behin betiko onartze data: 2019/06/21. 


\section{LABURPENA}

Artikulu honetan Bizkai mendebaleko XVIII. mendeko testu baten edizioa eta hizkuntza-azterketa aurkezten ditugu. Bilboko eskribau-etxe batean 1770ean sortutako dokumentu judiziala da, eta Zollon (Bizkaia) ezagutarazteko prestatu zuten. Testuak euskararen corpus historikoko hutsune bat betetzen du, eta interesa du bai generoari dagokionez, bai alderdi geolinguistikoari eta historikoari dagokienez. Bada, lan honetan testua sortu zen testuingurua hobeto ulertzeko azalpenak, testuaren edizio kritikoa, testuko ezaugarri linguistiko nagusien azterketa eta hizkeraren filiazio linguistikoari buruzko proposamena ematen dira.

Gako hitzak: mendebaleko euskara; edizio kritikoa; Lehen Euskara Modernoa; soziolinguistika historikoa.

\section{RESUMEN}

En el presente artículo damos a conocer una nueva fuente para el estudio del euskera occidental del siglo XVIII. Se trata de un documento judicial redactado en una escribanía de Bilbao en 1770, que fue preparado para ser dado a conocer en Zollo (Bizkaia). El texto, por lo tanto, viene a cubrir uno de los huecos existentes dentro del corpus histórico de la lengua vasca, y resulta interesante tanto desde el punto de vista del género textual como desde el de la geolingüística y la época. El presente trabajo presenta una introducción histórica que permite comprender mejor el contexto en el que fue creado el texto y una edición crítica del mismo. Además, analizamos los principales rasgos lingüísticos y proponemos una hipótesis sobre la filiación de la variedad lingüística atestiguada.

Palabras clave: euskera occidental; edición crítica; Primer Euskera Moderno; sociolingüística histórica.

\section{ABSTRACT}

In this paper, we present a new source for the study of the $18^{\text {th }}$ century Western Basque. It is a judicial document written by scribes in 1770 in Bilbao, and it was prepared to be exhibited in Zollo (Biscay). Therefore, the text comes to fill one of the gaps in the historical corpus of Basque, and it is interesting because of the textual genre as well as from the geolinguistic and chronological points of view. After a historical introduction, whose aim is to better understand the context in which the text was created, we present a critical edition. Furthermore, we analyse the main linguistic features and we propose a hypothesis about affiliation of the text's linguistic variety.

Keywords: Western Basque; critical edition; First Modern Basque; historical sociolinguistics. 


\begin{abstract}
1. Sarrera. 2. Agiria bere testuinguruan. 2.1. Auzi-gaiak. 2.2. Auziaren sustatzailea: Andrés de Arbide «El soldado». 3. ZoLLO. 3.1. Zenbait zertzelada historiko. 3.2. Zolloko eguneroko hizkuntza: euskara. 4. ZOLLOKO GALDETEGIA: DESKRIPZIOA ETA EGILETZA. 4.1. Deskripzioa. 4.2. Egiletza. 5. EDIZIOA. 5.1. Edizio-irizpideak. 5.2. Edizioa. 5.3. Ohar paleografikoak. 5.4. Euskarazko testuan egindako zuzenketak. 6. OHARRAK GRAFIAZ ETA TESTUAREN HIZKUNTZAZ. 6.1. Grafia eta hotsak. 6.2. Fonologia. 6.3. Izenaren morfologia. 6.4. Aditzaren morfologia. 6.5. Sintaxia. 6.6. Lexikoa. 7. TESTUKO EUSKARAREN KOKAPEN GEOGRAFIKOAZ. 8. HiZTEGIA. 9. ERREFERENTZIAK. 9.1. Iturriak. 9.2. Azterlanak. 10. ERANSKINAK: EUSKARAZKO PASARTEEN FAKSIMILA.
\end{abstract}

\title{
1. SARRERA
}

Euskararen historia aztertzeko corpusaren txikitasun erlatiboa txikitasun, azken hamarkadotan arian-arian agertu eta argitaratu izan dira euskalki guztietan idatzitako testu berriak: luzeagoak zein laburragoak izan, lagungarri izan dira hainbat hutsune betetzeko eta dialektologia-, soziolinguistika- zein historia-gaiez ikuspegi osoagoak eta egokiagoak lortzeko. Lan honetan, bada, orain dela hogei urte José Alfonso Antequerak Bizkaiko Foru Agiritegi Historikoan aurkitutako dokumentazioa aurkezten da; zehazki, auzi judizial baten karietara Bilboko eskribau-etxe batean sortutako eta Zollon 1770ean ezagutarazi beharreko galdetegi bat da, euskarara itzulita agertzen dena. Testua, horrenbestez, agiri administratibo eta judizialen corpusa (cfr. Trebiño, 2001, 2002; Urrutia, 2003; Urrutia \& Lobera, 1995) osatzeko baliagarri da, bai eta Bizkai sartaldeko (eta, are zehatzago, Bilboko eta Nerbioi ibarreko) euskararen bilakabide geolinguistikoaz zein zenbait ezaugarriren iraupenaz aritzeko ere.

Era honetako agiriak ahalik eta zehatzena aurkeztu behar direlakoan, aurkitutako dokumentazioari lotutako hainbat alderdi landu ditugu. Sarrera $(\mathbb{1}$ ) orokor honen ondotik, dokumentazioaren testuingurua aztertzen dugu $(\mathbb{S})$, auzi-gaiak zein diren eta auziaren sustatzailea nor izan zen argitzeko. Ondoren $(\mathbb{S}$ ) Zollori buruzko argibideak ematen ditugu: kokapenari, bilakabide historikoari zein egoera soziolinguistikoari lotutakoak. Hurrengo atalean $(\mathbb{S} 4)$ agirien deskripzioa, egiletzaren inguruko datuak eta hipotesiak agertzen dira. Horien guztien jarraian $(\mathbb{S} 5)$ testua editatzeko irizpideak $(\mathbb{S} 5.1)$, testuaren beraren edizioa $(\mathbb{S} 5.2)$, ohar paleografikoak $(\mathbb{S} 5.3)$ eta euskarazko testuan egindako zuzenketak ( $\mathbb{S} 5.4$ ) zehaztu dira. Ondoko ataletan hizkuntzaren 
azterketari lotutakoak daude: lehenik, hizkuntza-ezaugarri nagusien iruzkina (\$ 6); bigarrenik, ezaugarri horiek aztertuta hizkeraren jatorriaz proposamen bat ( $\mathbb{S} 7$ ); hirugarrenik, euskarazko testuko hitz guztiak biltzen dituen hiztegia $(\mathbb{S} 8)$. Azken ataletan erreferentziak $(\mathbb{9}$ ) eta euskal pasarteen faksimila $(\mathbb{S} 10)$ aurkezten dira.

\section{AGIRIA BERE TESTUINGURUAN}

\subsection{Auzi-gaiak ${ }^{1}$}

Hemen argitaratzen dugun testua Andrés de Arbide e Ypiñazarrek ${ }^{2}$ sustatutako auto judiziala da, antzinako foru-erregimeneko jaurerriko korrejidorearen justizia-epaitegira bere amaorde Dominga de Salazarren aurka egiteko jo zuenekoa. Zehazki, Zolloko Etxatxu etxaldearen enbargatzea, lurretan biltzeko zeuden artoen jabetza eta bestelako alderdi juridiko batzuk dira auzi-gaiak.

Bizkaiko Foru Agiritegi Historikoko JCR0489/009 espedientean islatzen den informazioaren arabera, Andrés de Arbideren eskaerari jarraikiz auzi judiziala jaso eta onetsi zen, eta galdera-artikulatua aurkeztu Joseph Ángel Ruiz de Otheo jaunaren aurrean: Calahorrako eta La Calzadako apezpikutzako priorea eta bikario jenerala zen orduan, eta Juan de Luelmo jauna apezpiku.

Andrés de Arbidek Elizaren zentsura orokorra eskatu zuen, aurkez zitzakeen lekukoekin batera auziaren inguruko azalpenak eman ahal izateko. Hain zuzen ere, dokumentazioan gordetako galdetegiaren euskal bertsioa, zantzu guztien arabera Joseph de Aranzazugoitiaren eskribau-etxean prestatua, Zolloko San Martin elizan ezagutarazi behar zen.

Dokumentuetan islatutako auziaren jatorriari dagokionez, Domingo de Arbideren eta Dominga de Salazarren ezkontza (1738/06/05ean ezkondu ziren eta belazioa ${ }^{3}$ 1738/06/15ean egin zuten) hartu behar da aintzat; izan ere, orduan egin ziren Zollo aldeko Etxatxu, Goikolanda eta Pereagerrena etxaldeen jabe, eta hainbat ondasun,

1 Lan honetan auzi-gaien eta auzietan agertzen diren etxe, leku zein pertsonen inguruko informazioa Bizkaiko Foru Agiritegi Historikoko (BFAH hemendik aurrera) dokumentu-sorta hauetan aurkitu dugu: JCR0532/005 (1737) [alokairua], JCR0881/022 (1746) [fruitu eta errenten itzulpena]; JCR0985/009 (1753) [zenbait ondasunen itzulpena], JCR0192/004 (1754) [estuproa], JCR2664/005 (1764) [ondasunen jabetza], JCR1615/008 (1766) [maileguen ordainketa], JCR0489/009 (1770) [enbargatzeak] eta JCR0535 (1785) [errentaren eta olataren ordainketa].

2 Bizkaiko Elizaren Histori Arkibuan (BEHA) gordetzen diren agirien arabera, gurasoak Domingo de Arbide y Larrea eta Simona Ypiñazar y Urruticoechea ziren, 1723ko urtarrilaren 8an Zolloko Etxabarri oinetxean ezkonduak. Azken hori 1737ko abenduaren 29an hil zen, eta Domingo 37 urte zituela alargun geratu. Senaremazteek bi seme-alaba izan zituzten: Andrés (1723/11/02) eta Josepha (1729/01/08). Agiriok Interneten kontsulta daitezke: http://internet.aheb-beha.org/paginas/indexacion/n_indexacion.php [azken kontsultaren data: 2019/06/19].

3 Ezkontza-egintzari irmotasuna emateko ospakizun liturgikoa da belazioa: ezkontza-mezaren ondoren belazio-meza egiten zen, non ezkontideak belo batekin estaltzen baitziren. 
azienda, kreditu eta jabetza lortu zituzten. Egoera, ordea, aldatu egin zen senaremazteen semea, Andrés de Arbide, María de Urruticoechearekin ezkondu zenean (1755/05/30): aitak kudeatu zituen etxaldeak 1764ra arte, orduz geroztik jabetza horien guztien erdia erreserbatu zuen berarentzat eta, ohitura foralari jarraituta, hil ezkero semeari utzi zion azienda osoa.

Familiaren ondarearen inguruan zenbait eztabaida sortu ziren; hain zuzen, badirudi gatazkaren iturri zirela Etxatxu etxaldearen erdiaren gozamena, Domingo de Goyri koinatuarekiko auzi luze batek ${ }^{4}$ eragindako gastuak eta amaordeak zenbait ondasun bereganatu izana.

\subsection{Auziaren sustatzailea: Andrés de Arbide «El soldado»}

Andres de Arbide e Ypiñazar 1723ko abenduaren 2 an jaio zen, eta gazte-sasoi oso gorabeheratsua eta gatazkatsua izan zuen: harroa ei zen, eta jendeak nahiago izaten zuen harekin ez ibili. María de Urruticoechea y Larrearekiko ezkontza-hitza ez betetzearren errejimentu-zerbitzura bidali zuten eta Kantabriako errejimentuan hogeita bi hilabetez eman zuen zerbitzu, zigorra bost urtekoa izan arren: handik zetorkion «El soldado» izengoitia. Gerora, gaixorik omen zegoela eta, lizentzia lortu zuen eta sorterrira itzuli zen. Hain zuzen ere, errejimentu hartan eskopeta trebetasunez erabiltzen ikasi zuen, eta ehizarako erabiltzeaz gain, auzokideen bistan ibili ohi zuen jendea uxatzeko. Bere jokamoldea, bizimodu okerra eta eskandalu publikoak zirela eta, Zolloko abade-erretoreak eta zegokion elizbarrutiko bikarioak hainbatetan hartu zioten kargu.

Zollora itzulita, bada, María de Urruticoechearekin harremanetan hasi zen berriz, eta 1755 ean ezkondu ziren Zolloko San Martin parrokian. Andrés de Arbidek Goikolanda etxaldearen jabetza jarauntsi zuen Francisco de Urruticoechea eta María de Basaurberen eskuetatik; hots, Domingo de Arbideren emazte Simona de Ypiñazar y Urruticoechearen gurasoengandik. Bestalde, amaren aldetik Simona de Ypiñazar y Urruticoecheak utzitako Ustara auzoko Pegarrena (Pereaguirrena, Peragarrena, Pereaguerrena oikonimoak ere agertzen dira agirietan) eta Etxatxu etxaldeak jaso zituzten. Andrés de Arbide ondasun horien erabateko jabe egin zen zegozkion ohore, erabilera-eskubide eta morrontzekin, Bizkaiko etxejaunei zegokienez. Jabetzak jabetza, ondasun horiek guztiak mantentzeko eta ez galtzeko zorpetu egin behar izan zuten senar-emazteek, eta ugaria da zor horiei aurre egiteko auzien inguruko dokumentazioa.

Andrés de Arbidek eta María de Urruticoecheak bi seme izan zituzten: Domingo eta Andrés de Arbide y Urruticoechea (1756/06/08an eta 1760/11/18an jaioak, hurrenez hurren, АНЕВ/BEHAko bataio-agirien arabera). Hain zuzen, Andrés de Arbide aitak eta Domingo de Arbide seme zaharrenak jabetzei zegozkien betebeharrak hartu zituzten euren gain, eta senide eta auzokoekin borrokan aritu behar izan zuten etxalde, mendi

4 Bizkaiko Foru Agiritegi Historikoan gorde da, JCR2664/005 (1764) signaturarekin. 
eta lursailei etekinak atera eta ordaindu beharrekoak ordaintzeko: zorrak, seniparteak eta doteak aipatzen dira eskrituretan, besteak beste. Aurrekoez landara, taberna-etxe bat ere izan zuten, eta burdinolen industrian esku hartu zuten (ikatza egitea eta garraiatzea, eta Arrankudiagako Landaberde auzoko burdinolaren kontu-garbitzeak). Halaber, Bilbo-Pancorbo (Burgos) errepide berriak egiteko lanetan aritu ziren.

\section{ZOLLO}

\subsection{Zenbait zertzelada historiko ${ }^{5}$}

Zollo Bizkaiko hego-sartaldean dago, Uribe merindadearen hegoaldean, Nerbioi ibarraren mendebaleko mendialdean; zehazki, Belaute/Ganekogorta (998 m) mendiaren azpian. Muga administratiboei dagokienez, sartaldean du Enkarterri eskualdea (Bizkaia), iparraldean eta sortaldean Nerbioi ibarra (Bizkaia), eta hegoaldean Aiara eskualdea (Araba). Aipatzekoa da Zollo ez dela herrigune bakarra, ezpada zenbait baserri-auzo eta etxalde biltzen dituen eremua: Aspiuntza, Ustara, Elexalde, Etxabarri eta abar.

Inguruaren ekonomia-gunea mendialdea izan zen hainbat mendez, eta nekazaritza, abeltzaintza eta basogintza ziren beharleku nagusiak. Alabaina, horiek ez bide zuten etekin nahikorik ematen gorakada demografikoei aurre egiteko, eta jarduera osagarriak sortu ziren, hala nola burdinolak, errotak eta merkataritza-guneak. Historikoki, paisaiaren osagai izan dira soroak eta herri-lurrak, sagardi eta garitzak, abereentzako kortabasoak, ikaztobiak, astazainak, soroetan landutako bihiak ehotzeko erreka aldeko errotak eta burdina-manufakturak, erreka-bazter eta eremu umeletako artotzak, karea lortzeko kare-hobiak, gaztainak bildu eta mantentzeko kirikino-hesiak, ehiztariak... Mendialdeko bizimodua, azken batean, ibarren hondokoa, merkataritzaren ibiltoki zen errepidetik hur egiten zena.

Francisco de Coscojalesen arabera ${ }^{6}$, Arrankudiaga, Arakaldo eta Zollo mugakideak Arrigorriagako monasterioaren mende egon ziren Goi Erdi Aroan (Elorriaga, 1995; Labayru \& Rodríguez, 1967), eta gordetzen diren lehenengo agiriek (XI. mendea) islatzen dute egoitza erlijiosoaren jabeak harotarrak zirela; hots, Bizkaiko jaun izango zirenak. Arrigorriagako monasterioaren mendeko lurrak zabalak ziren: Belaute/Ganekogorta mendigune gehiena hartzen zuten, hala Nerbioi nola Cadagua ibaietarantz hedatuta. Zehazki, honako elizate eta auzune hauek zeuden Arrigorriagako Santa Maria Magdalenaren babespean: Arrigorriagako elizatea bera, San Miguel (Basauri) eta San

5 Atal hau osatzeko Bizkaiko historialari klasikoen lanei jarraitu diegu lehenik eta behin: begiratu bibliografian Iturriza (1884), Iturriza \& Rodríguez (1967), Iturriza \& Azkarraga (1985 [1885]), Labayru (1968-1972) eta Artiñano (1985 [1885]). Halaber, iturri klasikoetako informazioa azken urteotan argitaratutako ikerlan monografikoekin osatu da: begiratu Cifuentes (1993), Díaz de Durana (2006), Elorriaga (1995), García de Cortázar, Arizaga, Ríos eta Del Val (1985) eta Ramos (1993).

6 Iturrizak jasotzen du Antigüedades de Vizcaya eskuizkribuan. Liburuklik atarian kontsulta daiteke: http://www.liburuklik.euskadi.eus/applet/libros/JPG/parlamento/00027405/00027405.pdf 
Bartolome (Alonsotegi edo Aldanondo) atxikiekin; San Lorentzo (Zaratamo); Santa Maria (Arrankudiaga), Santa Marina (Arakaldo) eta San Martin (Zollo) atxikiekin; Bujanako lau luberriak (Zeberitxa, Bujana goikoa eta behekoa, Ortzekauko eta Beteluri), jurisdikzio zibila Bilbo hiribilduan zutenak; Markio auzo-barrendegia, Miravalles hiribilduaren mendekoa; eta bestelako baserri-guneak.

Gaur egun, Zollo Arrakudiagaren mende dago: XV. mendearen erdialdean sortutako elizatea da Arrankudiaga, eta garapen ekonomikoaren eta gorakada demografikoaren gurpilean fundatu zuten, besteak beste Arrigorriagako eliza nagusia urrun xamar zegoela argudiatuta (Elorriaga, 1995, 62-64. or.; Iturriza \& Rodríguez, 1967, I, 388. or.; Labayru, 1971, 86-87. or.). Hain zuzen, Arrigorriagaren eta Arrankudiagaren arteko distantzia XIV. mendearen amaieran areagotua zen, bien bitartean Miravalles hiribildua fundatu zenean (1375) Zeberio haranetik hur, Ugao zeritzon inguruan. Fundazioak Nerbioi ibarra bitan zatitu zuen (iparraldeko eta hegoaldeko eremuetan), eta Arrankudiaga behin betiko bereizi: lehenbizi, Arrigorriagako elizatik bereizi zen; ondoren, Arrigorriaga elizatetik.

XV. mendean egoera ekonomiko onaren gurpilean biztanleria hazi zen, eta horrek tokian tokiko erakunde juridiko-administratibo berriak sortzeko aukera eman zuen; besteak beste, Zolloko etxaldeetako bizilagunek izan zuten horretarako aukera: parrokia-tenplua, hilerria eta kanpandorre bana eratu zituzten 1518an, Toursko apezpiku San Martinen deiturarekin, Arrankudiagako parrokia-eliza urrun zegoela eta esparru sakratu berri bati eusteko jende nahiko bazela argudiatuta. Martín Ruíz de Abendaño y Gamboa patroi banatzaileak ukoa eman zuen, eta bi urteko (1518-1520) auzien ondoren parrokia berria onartu zuen, betiere Arrankudiagakoaren menpe geratuta eta Zolloko bizilagunek Arrankudiagako elizaren patronatua onartuta; trukean, erlijiozerbitzuetarako abadea izendatzeko eta hamarren guztiak jasotzeko eskubideak eman zitzaizkien.

Alderdi zibilean, Gernikako Batzar Nagusiek ez zuten bereizketa onartu eta Batzarrotako bozketetan ahotsa zein jarlekua lortzea ukatu zioten Zollori: elizatea Arrankudiagaren menpe geratu zen. Nolanahi ere den, Zollok bereari eutsi zion, eta nahi bertsuak zituzten beste eremu mugakide batzuekin batuta, helegite eta apelazioak aurkeztu zituzten (Labayru, 1968-1972, IV, 2. liburua, VI. kapitulua, 268-269. or. eta VII. kapitulua, III. atala, 280-281. or.) harik eta 1553an Valladolideko Errege Kantzelaritzako Bizkaiko epaile nagusiak behin betiko epaia eman zuen arte: ez zen onartu Bizkaiko Konderriko eta Jaurerriko ofizio eta karguak hautatzeko eskubiderik.

Epaiak epai, Zolloko alkate, zinegotzi eta bizilagunek memorialak aurkezten jarraitu zuten, Bizkaiko Batzar Nagusietan egotea lortze aldera: hala egin zuten, adibidez, 1742 ko uztailaren 20an, lan honetan aurkezten dugun testuari dagokion garai bertsuan $^{7}$; erantzuna, baina, ezezkoa izan zen berriz ere. Halaber, 1800. urtean banatzeko

7 BFAH: AJ00451/003 dokumentu-sorta. 
beste saiakera bat egin zuten Arakaldoko elizatearekin batera, baina ez zuten arrakastarik izan eta Gernikako Batzar Nagusietan Arrankudiagaren menpe egon ziren harik eta 1877an Batzarrak eurak deuseztu ziren arte: hain zuzen ere, horregatik ez dira agertzen Arakaldo eta Zollo Batzarretara deitutako herrien artean: "Últimamente tenían voz y voto en las Juntas Generales 115 pueblos, de los 125 que contiene el Señorío: no tiene asiento en las Juntas Alonsotegui, Aracaldo, Zaratamo y Zollo» (Artiñano, 1985 [1885], 235. or. $)^{8}$.

\subsection{Zolloko eguneroko hizkuntza: euskara}

Zeharkako lekukotasunez harago, prozesu judizialek sarritan erakutsi dute Euskal Herriko hainbat lurraldetan euskarak diglosia-egoera bizi izan duela historikoki; alegia, etengabe erakutsi izan dute gaur egunera arte iritsi zaigun dokumentazio gehiena euskara ez beste hizkuntza batzuetan idatzita egon arren, herri xeheak eta, horrenbestez, herritarren gehiengoak, euskara baliatzen zuela eta, areago, biztanleria-masa horretara iristeko euskara baitezpadako tresna zela. Azken aldiko zenbait lan besterik ez ekartzearren, aipagarriak dira Nafarroari dagokionez Fernando Maiorak (2011, 2018), Peio Monteanok (2017) zein Ekaitz Santaziliak (2017, 2018, 2019) azken urteotan eginiko ekarpenak.

Ildo honetatik, eta epaitegietako auziei esker, lan honetan beste iturri bat gehitu diogu XVIII. mendeko Bizkaiko euskararen corpusari; zehazki, 1770eko testua da eta Joseph de Aranzazugoytia jaunaren eskribau-etxean idatzi zen, Bilbon. Orain arte uste izan da auzibideetako galdetegiak ahoz egiten zirela, nahiz eta euskaraz zirriborratutako testuak baliatzen zirelako susmorik ere egon den. Guri dagokigunez, zorionekoak gara, auzibideari lotutako galdetegia espediente judizialaren barnean gorde baita hiru mendez.

Hona dakargun dokumentuak baditu inplikazio soziolinguistiko interesgarriak, besteak beste bermatzen baitu 1770ean euskara zela Zolloko hizkuntza arrunta, gerora izan den legetxez. Zolloko bizilagunek euskara zerabilten XVIII. mendean; are gehiago, euskaldun elebakarrak bide ziren, eta horrek beharrezko egiten zituen hizkuntzabitartekariak (hizkuntza-bitartekarien lanaz, begiratu Madariaga, 2014, $\mathbb{6}$ 6). Besteak beste, elizgizonek mezetako eskaintzetan agintari erlijioso eta zibilen xedapen eta aginduak jakinarazten zituzten; gaztelaniaz idatzi ohi ziren, eta bitartekariek tokian tokiko hizkuntza arruntean eman ohi zituzten:

Aprovechando esta circunstancia, teniendo en cuenta el ascendiente social del que disfrutaban los curas para con la población en general y considerando que al menos una vez a la semana el conjunto de la feligresía (es decir la práctica totalidad de la población) se reunía en la misa popular, se estableció la costumbre de que los párrocos en el momento del ofertorio de la misa tradujesen al vasco los bandos que las

8 Begiratu, halaber, Bizkaiko Batzar Nagusietako aktok: BFAH AJ00487/003 (1770-1779); AJ01639/070 (1770); AJ0434/001 (1858); AJ0441/001, AJ0442/001, AJ0443/001 eta AJ0444/001 (1870-1877). 
autoridades, eclesiásticas y civiles, habían dado en romance, para el general conocimiento y para que nadie después pudiese alegar ignorancia sobre lo dispuesto. Estas traducciones públicas se conocieron generalmente con el nombre de publicatas (Madariaga, 2014, 305-306. or.).

Publikata horiek egiten zituzten, halaber, zeregin judizialetan zebiltzan eskribauek, fede-emaile publikoek eta udaletako idazkariek. Domingo de Arbide y Larreari lotutako datu bat interesgarria da Zolloko euskaren historia sozialerako: 1753ko abuztuaren 6an jakinarazpen bat egin zitzaion Domingori erreklamazio judizial batzuk zirela eta. Hau esan zuen Joseph de Barañano eskribau bilbotarrak:

...lei y notifique la peticion y auto precedentes [Reclamación como heredera universal] dando a entender en la lengua vulgar vazcongada, para su efecto en la persona de Domingo de Arbide vecino de esta referida Anteiglesia uno de los contenidos de dicha petición...9

Zolloko egoera soziolinguistiko modernoa ezagututa aurreko mendeetarako aurreikus zitekeena ziurtatzen dute, bada, aurrekoa bezalako aipuek eta lan honetan aurkezten dugun testuak.

\section{ZOLLOKO GALDETEGIA: DESKRIPZIOA ETA EGILETZA}

\subsection{Deskripzioa}

Lan honetan aurkezten dugun testua Bizkaiko Foru Agiritegi Historikoan gordetzen da; zehazki, atal judizialean (J), korrejimentuaren funtsaren barnean (CR) eta honako kode hauekin: JCR0489/009 (1770). Legajo 489, número 9.

Testu guztia hiru orri handitan biltzen da: lehenengo biak bertikalki eta erditik daude tolestuta, eta hirugarrena horizontalki eta erditik. Lehenengo orriak $1 \mathrm{r}, 1 \mathrm{v}, 2 \mathrm{r}$ eta $2 \mathrm{v}$ orrialdeak biltzen ditu; bigarrenak $3 \mathrm{r}, 3 \mathrm{v}, 4 \mathrm{r}$ eta $4 \mathrm{v}$ orrialdeak; eta hirugarrenak $5 \mathrm{r}$ eta $5 \mathrm{v}$ orrialdeak.

Edukiari dagokionez, bi zati nagusitan bana daiteke: alde batetik, auzi judizialean lekukoek azalpenak emateko galdetegi bat agertzen da, gaztelaniaz lehenengo eta euskaraz ondoren $(1 \mathrm{r}-4 \mathrm{v})$, biak ere eskuz idatzita; beste alde batetik, Calahorra eta La Calzadako apezpikutzak emandako eliza-zentsura dago (5r-5v), inprimatua eta hasieran eta amaieran eskuz idatzitako zenbait pasarte dituena. Hona hemen agirien eta edukiaren laburpen-taula:

9 BFAH: JCR0985/009 (1753), 17v eta 18r orrialdeak. 
1. taula. orrialdeak eta edukia

\begin{tabular}{|c|c|c|c|}
\hline Orria & Orrialdeak & Neurria $^{\mathbf{1 0}}$ & Edukia \\
\hline \multirow{3}{*}{1} & $1 \mathrm{r} \& 1 \mathrm{v}$ & $\begin{array}{c}305 \sim 311 \mathrm{~mm} \text { luze, } \\
420 \sim 426 \mathrm{~mm} \text { zabal }\end{array}$ & $\begin{array}{c}\text { Galdetegia gaztelaniaz } \\
\text { (1r \& 1v) }\end{array}$ \\
\cline { 2 - 4 } & $2 \mathrm{r} \& 2 \mathrm{v}$ & $\begin{array}{c}305 \sim 311 \mathrm{~mm} \text { luze, } \\
420 \sim 426 \mathrm{~mm} \text { zabal }\end{array}$ & $\begin{array}{c}\text { Galdetegia gaztelaniaz }(2 \mathrm{r}) \\
\text { eta orrialde zuria }(2 \mathrm{v})\end{array}$ \\
\hline \multirow{2}{*}{2} & $3 \mathrm{r} \& 3 \mathrm{v}$ & $\begin{array}{c}309 \sim 312 \mathrm{~mm} \text { luze, } \\
429 \sim 433 \mathrm{~mm} \text { zabal }\end{array}$ & $\begin{array}{c}\text { Galdetegia euskaraz } \\
\text { (3r \& 3v) }\end{array}$ \\
\cline { 2 - 4 } & $4 \mathrm{r} \& 4 \mathrm{v}$ & $\begin{array}{c}309 \sim 312 \mathrm{~mm} \text { luze, } \\
429 \sim 433 \mathrm{~mm} \text { zabal }\end{array}$ & $\begin{array}{c}\text { Galdetegia euskaraz } \\
\text { (4r \& 4v) }\end{array}$ \\
\hline \multirow{2}{*}{3} & $5 \mathrm{r} \& 5 \mathrm{v}$ & $\begin{array}{c}306 \sim 310 \mathrm{~mm} \text { luze, } \\
412 \sim 416 \mathrm{~mm} \text { zabal }\end{array}$ & $\begin{array}{c}\text { Elizaren zentsura } \\
\text { (5r \& 5v) }\end{array}$ \\
\hline
\end{tabular}

Eskuizkribuaren egoera fisikoa ona da: orriak osorik gorde dira, urradurarik eta testua irakurtzea eragozten duen orbanik gabe. Irakurtzen ez diren pasarte bakarrak egileek tintaz ezabatutakoak dira.

\subsection{Egiletza}

Bizkaiko Foru Agiritegi Historikoan auzi honen inguruan dauden dokumentu guztiak aztertuta, galdetegietan esku bat baino gehiago dagoelakoan gaude. Lehenik, gaztelaniazko galdera-sorta goitik behera idatzi zuen esku batek $(<\mathrm{A}>$ eskua esango diogu). Bigarrenik, euskaraz emandako galdera-sortan bi esku bereiz daitezke: $<B>$ eskua deituko duguna lehenengo puntutik bederatzigarrenera (gehi hamahirugarrena, ezabatua), eta $<\mathrm{C}>$ eskua hamargarren eta hamaikagarren puntuetan.

Dokumentuen egiletza zehatzari dagokionez, ez dugu erabat ziur esaterik nork idatzi zituen, baina eskueran ditugun zantzuek Joseph de Aranzazugoytia Olivares ${ }^{11}$ eskribauaren eskribau-etxera garamatzate ${ }^{12}$. Hain zuzen ere, Joseph Aranzazugoytiaren 1770. urteko dokumentu-sortari dagozkion eskritura nagusiak begiratuta (cfr. BAHP/ AHPB: José de Aranzazugoitia 2627, 1770. urtea), eta bestelako azterketa kaligrafiko baten faltan, badirudi kaligrafiaren estiloa $<\mathrm{B}>$ eskuaren antzekoa dela (hots, euskarazko lehenengo bederatzi galderak eta hamahirugarrena, ezabatua, idatzi zituenarena), eta horrek pentsarazten digu hizpide ditugun agiriak bere eskribau-etxetik atera zirela eta Joseph Aranzazugoytiak berak idatz zezakeela zati nagusia. Auziko narrazioan ere

10 Orrien tamaina irregularra da.

11 AHEB/BEHAko datuen arabera, Thomas Aransasugoytia Urizar eta Bentura Olibares Sagarminaga zituen guraso (Artea-Elexabeitian ezkonduak 1715/08/27an), 1718ko urtarrilaren 6an bataiatu zuten Bilboko Santiago parrokian, eta Francisca Theresa Achutegui Marurirekin ezkondu zen 1742ko irailaren 30ean (belazioa 1744ko urtarrilaren 21ean izan zen leku berberean), Bilboko bertako San Juan Abad elizan. Emaztea ere eskribau-habeko alaba zen.

12 Jabeak Garmako maiorazkoko jabeak ere baziren, fundatzaileen ondorengoak: Phelipe de la Garma y La Puente eta Magdalena de Novia y Salazar (cfr. BFAH JCR0695/010, 1767 auzia). 
horren aldeko zantzuak aurkitzen dira, dokumentazioan eskribau haren izena aipatzen baita $^{13}$.

\section{EDIZIOA}

Lan honetan 489/9 auziari dagokion testu osoa ematen dugu, nahiz eta gehien interesatzen zaigun zatia euskarazko galdetegia izan. Testu baten edizio kritikoa aurkezten dugu hemen, eta hiru motatako oharrak egin ditugu: lehenik, edizioaren ostean bildu ditugu ohar paleografikoak ( $\mathbb{S} 5.3$ ); bigarrenik, aurrekoen ondotik eman ditugu euskarazko testuan egindako zuzenketak $(\mathbb{S} 5.4)$; hirugarrenik, pasarteen argigarri izan daitezkeelakoan, oin-ohar azaltzaileak gehitu ditugu.

\subsection{Edizio-irizpideak}

Hona dakarguna testu elebiduna izanik, hizkuntzaren araberako edizio-irizpideak erabili ditugu, atalaren hizkuntza zein den. Gaztelaniazko pasarteak editatzeko, CHARTA nazioarteko sareak edizio kritikoak aurkezteko proposatutakoei jarraikiz aritu gara ${ }^{14}$. Euskarazko testua emateko, aldiz, honako irizpide orokor hauek baliatu ditugu:

- Orrialdeak zenbakitu ditugu, recto eta verso banaketa erabiliz (1r, 1v, 2r, 2v...). Zenbakiak emateko, orri guztiak hartu ditugu aintzat, dokumentu bakarra izango balitz bezala. Bestalde, lerroak bosnaka zenbakitu ditugu, eta ohar paleografikoetan eta euskarazko testuan eginiko zuzenketen atalean orrialde-zenbakiaren ondoren hemen aurkezten den edizioko lerroa adierazi dugu.

- Letra larri eta xeheen erabilera eguneratu dugu.

- Puntuazioa eguneratu dugu.

- Hitz-banaketa eguneratu dugu, tartean aldaketa fonetikoak zeudenean izan ezik; bestalde, bereiz agertzen diren atzizki eta posposizioak <-> ikurraren bidez lotu ditugu.

- Gaztelaniaz agertzen diren hitzak letra etzanez eman ditugu.

13 Eskua Aranzazugoitiarena edo haren mendeko eskribauena ez izatera, Antonio Ventura Oteiza lizentziatuarena izan zitekeen: Bizkaiko jaurerriko eta Bilboko Kontsulatuko instantzia gorenetan aritu zen, eta korregidorearen ordezko izan zen 1782an. Begiratu honako irizpen hauek: BFAH Consulado 0572/001/103 (1766); Consulado 0572/001/145 (1770); Consulado 0278/001/003 (1772); Consulado 0278/001/006 (1779). Bilbao Antigua 0445/001/017 (1770).

14 https://www.redcharta.es/criterios-de-edicion/ [Azken kontsultaren data: 2018/08/25]. 
- Laburdurak osatu ditugu.

- Testuko hutsuneak [ ] ikurren bidez bete ditugu. Puntu honi zein aurrekoari loturik, ortografia-arazoak sor zitezkeen kasuetan egungo idazkera arautua baliatu dugu. Esate baterako, txistukari frikariak emateko euskarazko forma etimologikoak eman ditugu.

- Izen bereziak zeuden-zeudenean utzi ditugu.

- Testuan gutxieneko aldaketa grafikoak egin ditugu:

- $<\mathrm{u}>$ eta $<\mathrm{v}>$ bokal ala kontsonante diren banatu ditugu.

- $<$ ç> pro $<\mathrm{c}>$ agertzen denean $<\mathrm{c}>$ eman dugu.

- Bokal artean $<$ r> pro $<$ rr $>$ agertzen denean $<$ rr $>$ eman dugu.

- $\quad<$, i $>$ aurretik $<$ g $>\rightarrow<$ gu $>$ bihurtu dugu.

- Azentu grafikoak kendu ditugu, esanguratsuak ez direlakoan.

- $<\mathrm{tt}>$ digrafoa $<\mathrm{t}>$ bihurtu dugu.

\subsection{Edizioa}

$<1$ r $>$ Articulado

Por las preguntas siguientes serán examinados los testigos que fueren presentados por parte de Andrés de Arrvyde en la causa con Dominga de Salazar, viuda, ambos vezinos de la Ante Yglesia de Zollo, sobre el desembarazo de la casa y casería de Echachu, sita en la misma ante yglesia, pertenencia de los maízes pendientes en sus heredades y otras cosas.

$5 \quad 1^{a}$ Primera: serán preguntados por el conocimiento de las partes notizia de'ste punto y causa, y por las demás generales de la ley real, etcétera.

2 Y si saven que la referida Dominga de Salazar únicamente llevó al matrimonio que contrajo con Domingo de Arvide, padre legítimo que fue de el articulante, la ropa y vestidos de su persona que por menor se expecifican en la escritura de capitulaciones matrimoniales, y cartas de pago que produxo en el proceso de dicha causa, y que todos ellos con el aumento de otros muchísimos ha tenido y tiene guardados en sus proprias arcas. Digan lo que supieren y, en lo demás, remítanse a dichas escritura y cartas de pago que para el efecto se les manifestará, etcétera.

153 Y si saven que el expresado Domingo de Arvide estubo gozando juntamente con la enunciada Dominga, su muger en segundas nupcias, enteramente la nominada casería y las de Goycolanda y Pereaguerrena hasta que dicho Andrés de Arvide contrajo su matrimonio y, después, hasta el día diez y ocho de agosto de mil setecientos sesenta y cuatro, las dos y media, por haverle cedido 
tansolamente la metad del aprovechamiento de dicha cassería de Pereaguerrena, y desde el citado día hasta su fallezimiento la metad de estas tres casas, y que con este motivo adquirió bienes muebles y semovientes, créditos y haveres de considerable entidad y estimación. Digan y den razón, etcétera.

4 Y si saven que de todos estos bienes, créditos y haveres se halla apoderada la expresada Dominga de Salazar, sin que hubiese hecho xurídico ymbentario de ellos, con el fin de que no se averiguase su ymporte y montante. Digan y den razón, etcétera.

5 Y si saven que el sobre dicho Domingo de Arvide al tiempo de su muerte tenía que aber un doblón de a ocho en Manuela de Yturriaga, otro en Don Melchor Ochoa de Ysusi y otro en Juan de Arvide, su sobrino. Digan, etcétera.

6 Y si saven que dexó el mismo Domingo Arvide dos novillos en los montes de la precitada ante yglesia y la casa de su avitación bien $<1 \mathrm{v}\rangle$ provista de camas, arcas, trastes de cocina y de adorno de la misma casa, y también varios reales de que se ha valido y se está valiendo la misma Dominga como si fuesen suyos proprios. Digan y declaren lo que supieren, etcétera.

7 Y si saven que también ha tenido y tiene en su poder un cerdo que compró el mencionado Domingo. Digan, etcétera.

8 Y si saven que los maíses existentes en las heredades de dicha casería de Echachu se sembraron muchos días después de la muerte de el prenotado Domingo por Andrés de Arvide, articulante, y que a su costa se han governado y veneficiado, sin que haya intervenido en esto directa ni indirectamente la insinuada Dominga. Digan y den razón, etcétera.

9 Y si saven que la comida de los que concurrieron al sembrío y beneficio de los recordados maíces se compuso de tocino, cecina y granos, que dexó el sobre dicho Domingo de Arvide, y correspondían a su hixo Andrés por havérselos mandado en su disposición testamentaria el mismo Domingo. Digan, etcétera.

10 Y si saven que el mencionado Andrés de Arvide litigó un dilatado [pleito] con Domingo de Goyri, como marido legítimo de Ypiña Arvide, sobre la nulidad de la donación que le hizo el enunciado su padre y que, después de haver obtenido favorable determinazión, el mismo Goyri se ajustó con él, cediéndole la cuarta parte de toda la hazienda, y que sin embargo de esto estubieron dicha Dominga y su marido gozando la metad de la mesma hacienda, no correspondiéndoles sino con la revaja de dicha cuarta parte cedida. Digan, etcétera.

11 Y si saven que Domingo de Ypiñazar, abuelo materno que fue del prenotado Andrés de Arvide, legó y mandó de'ste dos vacas y un novillo, las que recivieron dicho Domingo de Arvide y su muxer, y los vendieron como si fuesen suyos proprios y se valieron y aprovecharon enteramente de su precio y valor. Digan, etcétera.

12 Y si saven que de la misma suerte vendieron diez y ocho cabras que se ymbentariaron por muerte de Ypiñazar, madre lexítima que fue del articulante, y se balieron tambien de una mula hasta que murió, sin que hubiesen permitido al menzionado Andrés que se valiese de ella en tiempo alguno. Yten de público y notorio, pública voz y fama, y común opinión sin cosa en contrario. $<2$ r $>$ Digan, etcétera.

Lizenciado Don Antonio Bentura de Oteyza. Mena. 
Concuerda con su original, que por aora queda en mi poder a que me remito, y en fe de que la causa que refiere se recivió a prueva por el señor correxidor de este Muy Noble y Muy Leal Señorio de Vizcaya, en testimonio de mí, el esscribano, con los ochenta días de la ley en tres de el corriente mes, signo y firmo yo, el esscri-

70 bano real público del número de esta Villa de Bilbao, en ella, a veinte de octubre de mil setezientos y setenta. En testimonio del escribano Joseph de Aranzazugoytia.

Concuerda con su original, que queda en mi oficio, en que doi fe.

$<3 r>$

Santiago Joseph de Chasco 1770

75 Don Joseph Ruiz de Otheo Calaorraco obispo jaunen partes, Calaorra eta Calzadaco provisore jeneralac $\&$ dirause obispadu onetaco abade eta cura jaun gustiai selan Andres de Arbidec, elesate onetaco ausoac, eguin deusen errelaciñoa daucala corregidoren aurrean ausia Dominga de Salazarregas, viac erri onetaco ausoac, Echachuco echea libreu daiensat, eta au ausiau errezibidu dala ynformaciñoetara.

80 Baita Andresec, eguiteco berari toquetan iacana, presentau dauela bere articuladua, seiñetan dagosen pregunta oneic.

Pregunta $2^{\mathrm{a}}$ Badaquie Dominga Salazarrecoc escondu sanean Domingo de Arbidegas es eula beste gausaric eroan matrimoñiatura bere usuco erropac [baino], seinsuc dirian dagosanac yfiniric contratuan, eta gustiac, beste aric ona eguin

85 ditusanacas, daucasala gorderic bere cashetan.

$<3 v>3^{a}$ Badaquie esan dan Domingo Arbidecoc bere emaste bigarrenagas batera gosadu eula Echachuco echea, baita Goicolanda eta Peragarrena, osoan, escondu artiño Andres Arbideco, eta guero abustuan amasorcigarreneguino, sein dan aurtengo urtean sei urte cumpliduec, aprobechamintuen erdiac, eta motibu onegas

90 isan situsela ondasun asco estimasiño andicoac.

4 Badaquie se onei[c] ondasun gustioc dauquesala bere poderean Domingac, eguin baga ynbe[n]tarioric, jaquin sein din seinbat ynportateuan ${ }^{15}$.

5 Badaquie Domingo Arbidecoc ylgo san demporan eucala dobloa sorsico bat artuben Manuela de Yturriaga-gan ${ }^{16}$, beste bat Don Melchor Ochoa Ysusico-

95 gan eta beste bat bere adisquide bategan.

6 Badaquie esan dan Domingoc echi situsala elesa onetaco basoetan secor bi, eta bera bisi san echea ondo conponiduric, selan dan oiacas, cashacas, eta sugateco $<4 \mathrm{r}>$ tresneriagas, eta gustiac daucasala bere poderean.

7 Badaquie Domingoc erosi euen lauoñeco bat daucala bere poderean bere emastec.

8 Badaquie se Echachuco soloco artoac erein siriala Domingo yl asquero Andresen partes, eta onen costura gobernau diriela.

9 Badaquie se eguin san gastua arto ereitietan componietan sala urdaia eta cesinagas, Domingoc echi situsanacas, eta oneic toquetan yacasala aguindu eusasan partes Andres bere semeari.

15 seinbat ynportateuan: 'zenbat balio zuen', gaztelaniazko importe importar-i 'zenbateko, balio izan' loturik.

16 Pasarte iluna izan daiteke, artuben esparru juridikoko hitz teknikoa baita; lehen begi-kolpean aditz nagusia eta laguntzailea interpreta badaitezke ere (hartu eben), egiazki harturen 'kreditu, hartzeko, inork hartzekodun gisa hartzeko duena' berbaren aldaera da (OEH, s. v. harturen). 
10 Badaquie edo ensutia badauquie selan Andresec eucan ausi luse bat Domingo de Goirigas, Josepha de Arbiden senarrag[a]s, sein san oneri bere gurasoac eguin eusen donaciño-gaiti, eta urten asquero ausiyatan ondo ${ }^{17}$, Goiri ajustau sala Andresegas emonic acienda gustien laugarren partea, eta ones ostean Dominga eta bere senarra egon siriela gozetan hacienden erdiya tocau bagaric eurai.

11 Badaquie Juan de Ypiñazarrec, Andresen aitobec, aguindu e[u]sela oneri bey bi ta secor bat ${ }^{18},<4 v>$ eta oneic errezibidu situsela Domingo de Arbide ta bere emastec, eta bereac balisela legues saldu eudesela.

12 Badaqui[e] lo mismo balio eta saldu eudela ${ }^{19}$ amasorsi auns Simona de Ypiñasarrec echiyac, baita ygualmente mando bat, emon bagaric iñosco denporan Andreseri lecuric balietaco mandoagas.

Oneic dira pregunta gustiyac, eta alan prebenietan yaque daquianay dauquela excomuniño nagusian aurretic ${ }^{20}$ obligacio declarasera emeco maisu jaunen aurreti gustiya edo daquien partea. Bada, onetaraco libradu ditus censura oneic provisore jaunac.

13 Badaquie se Domingo de Arbidec eta bere emaste Domingac saldu situesala vederazi pago eta gabi ardaspat, Simona de Ypiñazarrec ychiac, euqui bagaric facultederic gozemenenac bayño.

$<5$ r $>$ Nos, el doctor Don Joseph Angel Ruiz de Oteo, provisor y vicario general

125 de este obispado de Calahorra y La Calzada, por el ilustrísimo señor Don Juan de Luelmo y Pinto, obispo del dicho obispado del consejo de su magestad. A los curas y clérigos de este dicho obispado: hacemos saver que por parte de Andres de Arvyde, vecino de la Ante Yglesia de Zollo, nos fue hecha relación diciendo [que] litigava pleito ante el cavallero corregidor de la villa de Bilbao con Dominga de

130 Salazar, viuda, vezina de dicha Ante Yglesia, y por testimonio de Joseph de Aranzazugoytia, escribano de dicha villa, [sobre] el desembarazo de la casa y casería de Echachu, sita en la propria Ante Yglesia, pertenencia de los maices pendientes en sus heredades y otras cosas. Que la causa se alla recivida a prueva y presentado su articulado de preguntas, de el que nos hizo exhivicion autorizado por el mismo

135 escrivano, pidiendo dicho significante censuras generales para poder testificar el tenor del dicho articulado por no poderlo hacer por otro medio, y por nos visto y reconocido, las mandamos expedir para que se publiquen en la dicha [Ante] Yglesia de Zollo y demás que combenga junto con el dicho articulado de preguntas que van firmadas por copia del presente notario que son las presentes, para que en

140 virtud de ellas declaren al tenor del dicho articulado los que supieren.

Y porque el mandamiento de Dios nuestro señor es que ninguno tome ni encubra lo ageno, en lo cual nos pertenece proveer como tales jueces eclesiásticos ordinarios. Mandamos que en vuestras iglesias y lugares todos los domingos y fiestas de nueve lecciones amonestéis y requiráis a las tales personas tomadoras, sabidoras y

17 urten asquero ausiyatan ondo: denborazkoa da.

18 Objektu pluralarekiko komunztadura falta bere horretan utzi dugu, ezaugarri linguistiko esanguratsua izan daitekeelakoan (begiratu 19. oin-oharra eta $\$ 6.5 .4$ atala).

19 Aurreko kasuan bezala, ez dugu komunztadura-falta zuzendu ( $c f r$. 18. oin-oharra eta $\ 6.5 .4$ atala).

20 excomuniño naguseian aurretic: eskumiku nagusia ezarri baino lehen. 
145 encubridoras de lo susodicho y de cada una cosa y parte de ello como por nos por las presentes amonestamos en virtud de santa obediencia y so pena de excomunión, que desde el día que esta nuestra carta les fuere notificada hasta seis días primeros siguientes que les damos y assignamos por tres canónicas moniciones, plazo y término peremptorio den, tornen, restituyan y declaren todo lo susodicho; y los sabi-

150 dores, tomadores y encubridores se lo digan a su cura. En otra manera lo contrario haciendo, ponemos y promulgamos en las tales personas tomadoras, sabidoras y encubridoras de todo lo susodicho, siendo rebeldes y contumaces, sentencia de excomunión en estos escritos, y por ellos.

Y assí cumplida la dicha nuestra carta monitoria, que de suso va incorporada, si

155 acaso fuere (lo que Dios nuestro señor no permita) que las tales personas tomadoras, sabidoras y encubridoras de lo susodicho no huvieren hecho la dicha restitución y manifestación según y como les fuere exortado y mandado, y estuvieren rebeldes y contumaces en su rebeldía y contumacia, os mandamos que en vuestras iglesias y lugares todos los domingos y fiestas de nueve lecciones denunciéis y hagáis denun-

160 ciar públicamente por tales públicos excomulgados como nos por las presentes los denunciamos por tales públicos excomulgados en estos escritos, y por ellos.

Y assí cumplidas las dichas nuestras cartas monitorias y denunciatorias que de suso van incorporadas. Y si acaso fuere (lo que Dios nuestro señor no permita) que las tales personas tomadoras, sabidoras y encubridoras de lo susodicho, y cada una

165 cosa y parte de ello no huvieren hecho la dicha restitución y manifestación, según y como les fuere exortado y mandado, y estuvieren rebeldes y contumaces en su rebeldía y contumacia, hechos miembros del Diablo, como si no fuessen christianos: os mandamos que en vuestras iglesias y lugares todos los domingos y fiestas de nueve lecciones denunciéis, por tales públicos excomulgados, a campanas tañidas

170 y candelas encendidas, matándolas en agua bendita, diciendo: assí sean muertas y malditas las ánimas de tales personas, y echadas con Judas el traydor, que está en el profundo del Infierno. Malditas sean de Dios, de Santa María y de todos los santos y santas de la corte del Cielo: ellos, el pan y carne que comieren, vino que bebieren y vestido que vistieren, y calzado que calzaren y la cama en que durmieren, y las

175 yerbas que pisaren: vivos los sorba la tierra como a Coré. Vengan sobre ellos todas las maldiciones que están en el psalmo: Deus laudem meam ne tacueris. Y assí estén malditas y excomulgadas hasta tanto que vengan al mandamiento de la Santa Madre Iglesia y a unión de los fieles cristianos. Y de cómo lo cumplieredes nos haced relación. Y mandamos que las manifestaciones que a estas nuestras letras se hicieren

180 se hagan ante los curas de las iglesias donde se leyeren y publicaren, a quienes para recibirlas damos comissión, y hechas, cerradas y selladas la embiad ante nos para que con vista de ellas proveamos justicia. Y mandamos que antes de publicar estas censuras el cura que lo huviere de hacer reciba su declaración jurada a la parte a cuyo pedimento van expedidas, de ser cierta su narrativa y no poderla justificar por

185 otro medio que el de ellas y que el valor o daño que se intenta reparar por medio de la justificación que se solicita excede de doscientos reales de vellón. Dada en Calahorra, a treinta y uno de octubre de mil setecientos y setenta.

Don Otheo

Por mandado del señor provisor 
Generales: sello. [su ylustrísimo]: procurador tierra

En esta Anteyglesia de Sollo, a diez y ocho de noviembre $<5 \mathrm{v}>$ y año de mil setezientos y setenta, yo, el esscribano real de su magestad y vezino de la Villa de Bilbao, de requerimiento de Andrés de Arbide, vezino de esta dicha anteyglesia, hize

195 presente ley y requerí con las zensuras prezedentes y articulado de preguntas que ba por principio de ella, para su azeptazión y cumplimiento, y se publiquen, según y en la forma que se prebiene en persona a Don Juan Antonio de Jugo, presvitero y único cura y veneficiado de esta dicha anteyglesia, quien enterado de sus efectos, hallándose presente dicho Andrés de Arbide, dijo que por ser falza la narratiba del

200 encabezado de estas zenzuras, es a saber que no puede encontrar testigos para la justificazión de las preguntas de dicho articulante, y no exponer al susodicho a un juramento falzo, y por ebitar escándalos y escrúpulos de conciencias timoratas, siendo así que dicho Andrés tenía testigos suficientes y promptos para deponer de lo que sabían sobre el articulado, no azeptaba la comisión que se le confiere,

205 ni permite que se lean y publiquen dichas zensuras por las razones referidas. Esto respondió y firmó, y a este tiempo dicho Andrés expuso que protestaba y protestó todos los daños, gastos y perjuicios que se le podían ocazionar por razón de la falta de la lectura de dichas zensuras, y no tener otro fin para no permitir a ello y dar su devido cumplimiento sino el de ser dicho Don Juan Antonio, parte que mira a

210 Dominga de Salazar, su contrincante, con quien pasó a consultar adonde el abogado director y a[genciar] por si dicho pleito y a más de ello dar horden a fiel rexidor de esta dicha anteyglesia, para que los maízes que se recojieron de las heredades de la casería de Echachu, sobre que es dicho pleito, pusiese en ella y recojiese todas las llabes, pues, en caso de que al susodicho le sobrebiniese por ello algún daño,

215 salía desde luego a su abono y fianza. No firmó dicho Andrés y, en fee de todo, lo hize yo, el dicho esscribano.

Don Juan Antonio de Jugo

Manuel de Achutegui

\subsection{Ohar paleografikoak}

1r-1 Artic ${ }^{d o}$ : articulado hitzaren laburdura; orrialdearen goialdean dago, ezker muturrean eta testu nagusitik kanpo, hezetasun-orban baten gainean.

1r-2 examinados: $<\mathrm{x}>-\mathrm{ak}<\infty>$ itxura du eta $<\mathrm{xx}>$ dagoela ere pentsa liteke, baina $<\mathrm{x}>$ bakarra da.

1r-3 Andrés: $<\mathrm{n}>-\mathrm{a}<\mathrm{m}>-$-rekin nahas liteke, $<\mathrm{n}>$-aren eta hurrengo letraren artean eginiko lotura grafikoaren ondorioz.

1r-7: conocimiento: bigarren $<0>-\mathrm{a}$ ez da zirkulu oso bat eta $<\mathrm{e}>-$ ren tankera ere har dakioke.

1r-9 2: bigarren puntuaren aldamenean, behetik gora ageri da artxibozainen batek eskuizkribuari emaniko signatura: Leg. 489. $n^{\circ} 9$. 
1v-54 dicha: oro har, hala dicha nola dicho laburdura bidez (dho dha) adierazten dira; kasu honetan amaieran <s> dirudien marratxo bat dago, baina azken letraren apaingarria delakoa daukagu. Eskuizkribuan hainbat aldiz gertatzen da.

1v-56 de'ste: hitza( $(\mathrm{k})$ ez $\mathrm{d}(\mathrm{ir}) \mathrm{a}$ argi ikusten, eta lehen begi-kolpean veinte ere irakur liteke; aitzitik, testua arretaz aztertu eta euskarara eginiko itzulpena aintzat hartuta (cfr. 4r Andresen aitobec, aguindu eusela oneri bey bi ta secor bat) de'ste eman dugu, uzkurdura tarteko.

1v-63 común: hitz horren azpian de ageri da, aparteko lerrokada batean, zeri dagokion adierazi gabe.

2r-72 doi fe: azken lerroa eta sinadura letra handiagoz ematen dira. Bestalde, idazkera ez da argia: bi hitzak loturik ematen dira, $<\mathrm{d}>-\mathrm{k}$ ez du makilarik eta makila bakar batek adierazten bide ditu $<\mathrm{y}>$ eta $<\mathrm{f}>$-renak.

3r-75 Don: laburdura bidez adierazia, $<$ D $>$ gainerako hitzekin lerrokatuta eta $<n>-\mathrm{a}$ goratxoago. Artxibozainen batek lehenengo hitz honen gainean idatzi zuen eskuizkribuari dagokion signatura: Leg. 489. $n^{\circ}$ 9. Nolanahi ere den, testua arazorik gabe irakurtzen da.

3r-75 Calaorraco: lehenbiziko <o $>$-aren ordez $<\mathrm{u}>$ ere irakur zitekeen, zirkulua ez baitago guztiz itxita. <o> ematea erabaki dugu, testuko gainerako adibideetan hala agertzen delako.

3r-76 dirause: dardarkariaren gainean txapel edo marra baten irudia dago, baina ez dirudi azpiko hitzari lotu behar zaionik. Irautsi erroko aditza izanik, pentsa liteke irauntsi aldaerari ez ote dagokion eta txapela sudurkariaren ordez eman ez ote den, baina proposamenak baditu zailtasunak: alde batetik, «txapela»ez dago sudurkaria legokeen letren gainean, ezpada ezkerrerago; beste alde batetik, -iraun(t)s- erakoak Zabala (1848) lanean besterik ez omen daude (OEH, s. v. erauntsi, 6).

3r-80 berari: tinta faltaz edo, <a> ez dago osorik marraztuta; halere, datiboko komunztadura aintzat hartuta, aukerak ez dira askoz gehiago. Beroni jartzen duela ere pentsa liteke.

3r-80 dauela: lerro-aldaketak zatitzen du hitza (daulela). Menderagailua erabat argi ikusten den arren, aurreko lerroaren amaieran geratutako zatian deu ere irakur liteke (beraz, deuela esango luke testuak). Aukera hori guztiz baztertu ez arren, lehenengo aukera dakusagu argiago beste hitz batzuetan letrok duten itxurarekin alderatuta.

3r-82 Pregunta $2^{a}$ : orrialdearen ezker-alboan idatzita, letra txikiagoz. Aurretik pregunta hitza dakarren paragrafo bakarra da: gainerakoetan zenbakia besterik ez da ageri. 
3r-82 Badaquie: hitz amaieran ez <e> baina <c> dagoela pentsa liteke, trazua hain da fina. Halere, testuaren erdal bertsioaren argitan (si saven agertzen da hamabi aldiz), ematen du pluralgilea dagoela. Gainerako puntuetan argi irakurtzen da $<\mathrm{e}$.

3r-84 gustiac: $<\mathrm{tt}>$ digrafoa ezker-eskuin zeharkatzen duen marratxoak herskari aurreko txistukaria ere zeharkatzen duela eta, pentsa liteke $<\mathrm{z}>$ dagoela eskuizkribuan, baina $<\mathrm{s}>$ eman dugu, testuko $<\mathrm{z}>-\mathrm{k}$ ez baitute marratxo horizontalik eta hitz horretan sistematikoki ageri baita $<$ st $(\mathrm{t})>$ multzoa.

3v-86 emaste bigarrenagas batera: aurretik emastegas batera bigarrenagas idatzi zen, baina egileak berak zuzendu zuen soziatiboko marka batera hitza ezabatuta eta batera ondoren emanez.

3v-89 onegas: lehenengo bokalari ere $<\mathrm{g}>$-ari dagokion luzapena egin zaio behealdean (gonegas); are gehiago, lehenbiziko luzapen horrek tinta-orban bat du erdian (orban horretan biltzen dira, hain zuzen, $<0>$-aren eta $<$ g $>$-aren luzapenak), beharbada zuzendu egin nahi izan zelako, nahiz eta osorik ez ezabatu.

3v-90 isan situsela: hainbat hitzetan ez da erraza $<$ s $>$ edo $<\mathrm{Z}>$ den argitzea, marratxo bertikal soil batek islatzen baitu. Halere, $<$ s $>$-ren aldeko hautua egin dugu, letra argiago irakur daitekeen kasuetan hori ageri delako.

3v-93 demporan eucala: bi hitzen artean zerbait idazten hasi zen egilea (hizki bat gehienez ere: <e>?), baina ondoren guztiz ezabatu zuen.

3v-95 adisquide bategan: lerro artean idatzi da, aurretik idatzita zegoena ezabatu ondoren. Ezabatze-ahaleginak ahalegin, lehenbizi idatzi zena irakurtzea lortu dugulakoan gaude: bere [l]loba Andres Arbidecogan (edukiari dagokionez azken esaldi horrek zuzenketa bidez sartutakoak baino batago egiten du gaztelaniazko bertsioaren edukiarekin: 1r y otro en Juan de Arvide, su sobrino). Bestalde, ezabatutako [l]loba hitzaren hasierako marrek nahastea eragin dezakete, lerroarteko adisquide ukitzen baitute eta adinquide jartzen duela ematen baitu. Nolanahi ere den, marra bakoitza zeri dagokion zehatz aztertuta, irakurketa ziurra da adisquide.

3v-96 echi situsala: lerro-aldaketa tarteko, ezabatuta dago hasiera batean echi si-idatzi ondotik idatzi zena, eta testuak hurrengo lerroan jarraitzen du (tusala). Ematen du echi situa- idatzi zela lehenbizi, eta tua- hori ezabatu zela ondoren, plurala zuzentzeko.

3v-96 secor bi: ondoren zerbait idatzi zen (hizki bat edo bi gehienez), baina gero guztiz ezabatu z(ir)en.

4r-98 gustiac daucasala: gustiac horren ondotik zerbait idatzi zen (bi letra), eta ondotik ezabatu. Ezinezko izan zaigu lehenbizi idatzitakoa irakurtzea. 
4r-99 erosi euen: zalantza edo erabaki-aldaketa islatzen du hitzak, bigarren <e> hori nabarmendurik ageri baita, aurretik idatzitakoa (<a>?) zuzendu nahi izan balitz bezala.

4r-102 costura: <tt> digrafoa ezker-eskuin zeharkatzen duen marrak zalantzak eragin ditzake, ez ote duen contura jartzen; halere, costura irakurtzen dugu ( $c f r$. gaztelaniazko $1 \mathrm{v}$ a su costa). Bestalde, hurrengo lerro osoa ageri da marratxo gurutzatuz ezabatuta. Azpian hau irakurtzen dugu, berbaz berba: sartu bagaric esetan Dominga Salasareco.

4r-103 sala urdaia: bitartean seindan idatzi zuen egileak, eta ondoren marratxo gurutzatuen bidez ezabatu.

4r-103 eta: ezker zutabean ageri da, egileak idaztea ahaztu eta ondoren sartu izan balu bezala.

4r-106 10: hemendik aurrera (10. eta 11. puntuak) eta ia amaieraraino letra-moldea aldatu egiten da: txikiagoak dira letrak, eta lodiagoak trazuak.

4r-107 oneri: irakurketa hori egiten dugu esaldiaren gainerako elementuekin bat datorrelakoan, baina letren gaineko tinta-orbanek besterik estal dezakete: azken hizkiak gehiago du $<\mathrm{q}>$ baten antza (oneiq irakurri ahal izatea dakar horrek), baina gainean badu <i>-rena besterik izan ezin daitekeen markatxoa.

4r-110 eurai: azken hitz horren ondotik beste zerbait idatzi zen; zehazki, espada jartzen duelakoan gaude, baina tinta-marra horizontal lodi batek ezabatzen du.

4r-111 Juan: nahastuta, Dominga idatzi zuen egileak lehenbizi, eta ondoren ezabatu. Zegokiona, Juan, lerroartean dago.

4v-113 eta bereac: bi hitz horien artean txertatu zuen eudesela aditz laguntzailea, eta ondoren ezabatu.

$4 \mathrm{v}-114$ Simona de: izena lerro artean dago idatzita, zegokion lerroan $<^{\wedge}>$ itxurako dei bat txertatuta.

4v-117 Oneic dira: paragrafoko lehenengo bi hitzak ia batera ageri dira, itxuraz, zuzenketa baten ondorioz. Aditzaren hasierako $d$ - nabarmen markatuago dago, eta badirudi irakurri ezin den letraren bat estaltzen duela.

4v-121 13: hamahirugarren puntua euskarazko testuaren amaieran ageri da, eta elkar gurutzatzen duten marren bidez ezabatu zuen egileak. Nolanahi ere den, lerro guztiak irakur daitezke arazorik gabe. Bide batez, letra-moldeari dagokionez, 10. puntua baino lehenagokoa ageri da berriz (handiagoa eta trazua meheagoa). 
4v-121 emaste: hitz horri markaren bat gehitu zitzaion hasiera batean (ergatiboko $-c$, ziur asko), eta ondoren ezabatu.

5r-186-187 Calahorra: lekua eta data eskuz idatzi ziren. Orobat ondoko sinadura.

5r-188 Por mandado del señor provisor: esaldi hau inprimaturik ageri da; alegia, ez da eskuz idatzi. Horren ondoko guztia bai, eskuz idatzi zen.

5r-191 Generales: hitzaren laburdura zigiluaren azpian dago, eta zigilua zertxobait altxatu behar da ikusi ahal izateko.

5r-191 sello: ondoko laburdurak interpretatzea ez da aise, idazleak laburdurak eta apaindurak baliatu baitzituen: hasierako zirrimarrak $<$ SYL $>$ letren antza du, eta ondoren $<$ mu $>$-ren itxura duen elementua agertzen da, txapela gainean. Horren argitan, su ylustrisimo-ren laburdura izan daitekeelakoan gaude eta hala eman dugu, baina irakurketa ez da ziurra.

5r-192 noviembre: agiriaren azken orrialde honetan, ezkerreko zutabean artxibozainen batek eskuizkribuari emaniko signatura agertzen da berriz, behetik gora idatzita: Leg. 489. $N^{\circ} 9$.

5v-2014 por ello: Por e ello dio testuak, zehazki. Hitzen arteko <e> ez dago oso markatuta.

\subsection{Euskarazko testuan egindako zuzenketak}

2r-66-67 y en fe y de que] y en fe de que || 3r-77 errelacioñoa] errelaciñoa || 3r-79 ynformacioñoetara] ynformaciñoetara || 3r-85 casehtan] cashetan || 3v-89 situsuela] situsela || 3v-87 echean] echea || 3v-90 estimaisiño] estimasiño || 4v-116 mandoa-gan] mandoagas || 4v-118 naguseian] nagusian.

\section{OHARRAK GRAFIAZ ETA TESTUAREN HIZKUNTZAZ}

\subsection{Grafia eta hotsak}

\subsubsection{Txistukarien adierazpena}

Testuaren ezaugarri grafiko nabarmenena txistukarien adierazpena da.

Alde batetik, frikariak eta afrikatuak ez dira grafikoki ezberdintzen; beraz, testuak batago egiten du Hego Euskal Herriko 1745 aurreko bereizketarik ezarekin, Lehen Euskara Modernoko joera berriekin baino (Lakarra, 1985, 242. or. eta hurrengoak). Arazo ezagun askoa da euskal testuen tradizioan (XVIII. menderako, begiratu Urgell, $2018, \mathbb{S} 5.2 .4$ ), eta ozen ondoko txistukariak frikari gordetzen ala afrikatu bihurtuak ziren erabakitzea eragozten du: $c f r$. $3 \mathrm{r}$ daiensat, $3 \mathrm{r}$ seinsuc, $4 \mathrm{r}$ ensutia, $4 \mathrm{v}$ auns; $3 \mathrm{v}$ sorsico, $3 \mathrm{v}$ amasorcigarreneguino, $4 \mathrm{v}$ amasorsi. 
Beste alde batetik, egileak $<$ s $>$ eta $<$ ch $>$ grafemak baliatu zituen gehienetan txistukariak adierazteko. Hain zuzen ere, Zolloko galdetegiak bat egiten du mendebal zabaleko beste testu arkaiko, zahar eta moderno batzuetako erabilerarekin, $<$ s $>$ grafemaren bidez adierazten baitira / $\mathrm{f} / \mathrm{ez}$ gainerako txistukariak, kokagunea edozein izanda. Hala gertatzen da bai apikari frikari eta afrikatuetan ( $c f r .3 \mathrm{r}$ beste, $3 \mathrm{r}$ osoan, $3 \mathrm{v}$ basoetan, 4v saldu; $4 \mathrm{r}$ eusasan, $4 \mathrm{r}$ eusen, $4 \mathrm{r} e[u]$ sela), bai lepokari frikari eta afrikatuetan (3r gustiai, 4v ditus, $3 \mathrm{r}$ sanean, $3 \mathrm{r}$ ausiau; $4 \mathrm{v}$ balisela eta $4 \mathrm{v}$ declarasera). Salbuespen gehien-gehienak gaztelaniatiko maileguetan eta izen propioetan metatzen dira: $3 \mathrm{r}$ errelaciñoa, 3r errezibidu, 3r ynformaciñoetara, 4r donaciño-gaiti, 4r acienda, 4r gozetan, $4 \mathrm{v}$ errezibidu, 4v obligacio, $4 \mathrm{v}$ censura, $4 \mathrm{v}$ gozemenenac; 3r Ruiz, 3r Calzadaco, 3r Salazarregas, 3r Salazarrecoc, 4v (birritan) Ypiñazarrec. Aitzitik, birritan agertzen dira $<\mathrm{c}>$ eta $<\mathrm{z}>$ ondare zaharreko hitzetan; zehazki, zenbakiei lotuta: $3 \mathrm{v}$ amasorcigarreneguino eta $4 \mathrm{v}$ vederazi.

Sabaikarietan, Dotrinazko sermoitegia-n bezala (cfr. Ulibarri, 2015, $\mathbb{S}$ 4.2.1.4), Zolloko galdetegiaren egileak $<\mathrm{s}>$ erabili zuen gehienetan $/ \mathrm{f} /$ adierazteko: $3 \mathrm{r}$ elesate eta 3v elesa. Salbuespen bakarra kaxa hitzari dagokio, birritan agertzen baita sabaikaria $<$ sh> digrafoarekin: $3 \mathrm{r}$ cashetan eta $3 \mathrm{v}$ cashacaz; <sh>-k geroztik izandako bilakaeraz, begiratu Urgell (1987, 360-365. or. eta 2018, 608-209 eta 613. or.) eta Ulibarri (2015, 316. or.). Bestalde, Hego Euskal Herrian erabat ohiko izan da /t $\mathrm{f} /$ adierazteko $<\mathrm{ch}>\mathrm{era}-$ biltzea, Zolloko galdetegian bezala: 3r Echachuco, 3r echea, 3v echi eta abar.

Aurreko egoerak erabat zailtzen du txistukarien neutralizazioaz ezer ziurrik baieztatzea: $<\mathrm{z}>$ eta $<\mathrm{c}>$ duten kasu gehienak mailegatutako hitzak izatea esanguratsua da, eta erabilera grafiko gordetzailearen ondorio direla pentsarazten digute. Halaber, izen berezietako $<\mathrm{z}>\mid<\mathrm{s}>$ txandaketak onomen idazkera fosilduari egotz dakizkioke. Euskal ondare zaharreko hitzetan, bestalde, $<\mathrm{c}>$ eta $\langle\mathrm{z}>$ duten adibide bakarrak zenbakiei lotuta agertzeak ( $3 \mathrm{v}$ amasorcigarreneguino eta $4 \mathrm{v}$ vederazi) zalantza eragiten digu, ez ote diren beste nonbait irakurrita ikasitako formak. Horiei loturik, gainera, garaitiko adibideetan ez dago <z>-ren bidez adierazitako lepokaririk, $3 \mathrm{v}$ amasorcigarreneguino-rekin batera $3 \mathrm{v}$ sorsico eta $4 \mathrm{v}$ amasorsi baitaude; halaber, ez dut hiperzuzenketakasurik aurkitu. Ulibarrik $(2015,138$. or.) Dotrinazko sermoitegia-n erabilitako irizpideekin bat, neutralizazioaren zantzu bakana $3 \mathrm{v}$ gosadu maileguan egon liteke $(4 \mathrm{r}$ gozetan eta $4 \mathrm{v}$ gozemenenac formekin batera agertzen da euskal pasartean, nahiz eta gaztelaniazko testuan goz- besterik ez dagoen). Forma horretan oposizioa galdua zela dagoela onartuz gero, gogoan hartzekoa litzateke bokalarteko neutralizazio-kasu bat genukeela, eta, hortaz, pentsatzekoa da neutralizazioa errazago gertatzen den kokaguneetan behintzat aurreratuago egon behar zuela oposizioaren galerak, nahiz eta testuak ez duen hori bermatzen.

6.1.2. Espainiako Errege Akademiaren Ortographia española (1741, 226-233. or.) aitzindarian latindar testuez aritzean zenbait kontsonante bikoizteko ohitura deskribatzen da, eta, besteak beste, <tt > bikoitzak aipatzen dira. Ezaugarriak ez du ezelako loturarik gaur egun euskaraz digrafo beraren bidez eman ohi dugun palatalizazioarekin, eta arrunt askoa da XVIII. mendeko gaztelaniazko testu juridiko-administratiboetan (cfr. Arnal, 2000 eta Marcet, 2007 Aragoiko eta Leongo notaritza-agiriez). Euskaraz, 
mendebaleko XVIII. mendeko testu batzuetan ere agertzen da, hala nola Arrasateko 1705eko udal-bandoan, Urkizuren Liburu Virgina Santissimien Errosario Santuena delakoan, Orozkoko 1739ko otoitzetan, Eibarko 1754ko udal-ordenantzetan, De la Quadraren lanetan eta Dotrinazko sermoitegia-n.

Zolloko galdetegian gehienetan bokal artean azaltzen bada ere, edozein kokagunetan ager daiteke <tt $>$ digrafoa bai euskal, bai erdal hitzetan; bai izen arruntetan, bai izen berezietan. Hona hemen adibide sorta bat: 3r Ottheo, 3r onettaco, 3r etta, 3r elesatte, 3r ynformaciñoettara; 3r \& 4r ttoquettan, 3v ttresneriagas; 3r daiensatt, 3v seinbatt, 3v \& 4r (birritan) \& 4v batt, 4v ardaspatt.

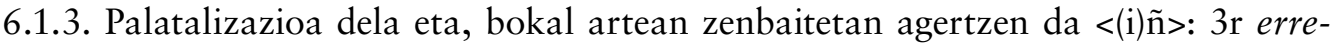
laciñoa, 3r ynformaciñoetara, 3r seiñetan, 3v artiño, 3v estimasiño, $4 \mathrm{r}$ lauoñeco, $4 \mathrm{r}$ donaciño, 4r \& 4v Ypiñazarrec, 4v Ypiñasarrec, 4v iñosco, 4v excomuniño. Nolanahi ere den, badaude salbuespenak: 3r yfiniric, $3 \mathrm{v}$ amasorcigarreneguino.

6.1.4. Bizkai sartaldean arruntagoa da herskari sabaikaria, eta hala islatzen du hizpide dugun testuak ere $<\mathrm{i}>$ eta $<y>$ grafemen banaketaren bidez. Funtsean, $<y>$ hitz hasieran eta diptongoen bigarren elementu bezala besterik ez dago: hitz hasieran, kontsonante aurrean /i/ bokala adierazten du (3r ynformaciñoetara, 3r yfiniric, 3v ynbentarioric, 3v ynportateuan, 3v ylgo, 3v Yturriagagan, 3v Ysusicogan, 4r yl, 4r \& 4v Ypiñazarrec, 4v Ypiñasarrec, 4v ygualmente, 4v ychiac), eta bokal aurrean sabaikaria (4r yacasala, $4 \mathrm{v}$ yaque). Kasuren batean, halere, <i>-k ere islatzen du kontsonantea hitz hasieran (3r iacana). Diptongoei dagokienez, oro har erdibokala $<\mathrm{i}>-\mathrm{z}$ adierazten da ( $3 \mathrm{r}$ baita, $3 \mathrm{v}$ sein, 3v sei eta abar), baina badago <y>-rik ere: 4r bey, 4v bayño, 4v daquianay.

Aipa dezagun, azkenik, /i/ bokalaren ondoko epentesi kontsonantikoa ere $<\mathrm{y}>$ bidez eman zuela idazleak: 4r ausiyatan, 4r erdiya, 4v gustiyac, 4v gustiya.

6.1.5. Euskarazko testuan $<\mathrm{j}>-\mathrm{k} / \mathrm{x} /$ belarra islatzen duela zalantzarik gabea da gaztelaniazko pasarteen argitan (cfr. 3r jeneralac, $4 \mathrm{r}$ ajustau), eta grafemen arteko banaketak zenbait lorratz ematen ditu euskaraz ere hitz batzuetan gauzatze fonetikoa hori izan zitekeela pentsatzeko, nahiz eta Bizkaiko mendebalean (Orozko aldean salbu) herskari sabaikaria izan orokor: 3r jaun, 4v jaquin, 4r Juan, 4v jaunen.

\subsection{Fonologia}

6.2.1. $-a+a>-e a$ disimilazio morfonologikoak eragindako berranalisien ondorioz, Mendebalean arrunt dira $-e>-a$ erako berreraiketak (lore $>$ lora), eta horren itxura du Zolloko galdetegiko 3v dobloa (< dobloe < gazt. doblón) aldaerak. Bestalde, Bizkaiko testuetan disimilazio berdina gertatzen da izan, joan eta eroan-en formetan, eta Zolloko galdetegian ere badago, izan-i loturik eta $e a \rightarrow i a$ aldaketa tarteko (cfr. $\$$ 6.2.2.): $2 \mathrm{v}$ dirian, $4 \mathrm{r}$ diriela, $4 \mathrm{r}$ siriala, $4 \mathrm{r}$ siriela.

6.2.2. Bizkai sartaldeko hizkera gehienak gordetzaile dira jaurerriaren erdi-ekialdean arauzko den $e \rightarrow i$ /_ $V^{(a, e, o)}$ berrikuntzaren aurrean, eta badira araua hartu ez 
duten hizkerak (Arratia, Zeberio, Nerbioi ibarraren hegoaldea, Txorierriko zenbait herri, Uribe Kosta, Mungialdeko zenbait auzo) zein kasu batzuetan bakarrik hartu dutenak (Orozko, Zeanuri). Bizkai sartaldean, aldiz, Nerbioi ibarraren iparraldeko eta Bilbo hegoaldeko euskarak hausten du gordetzailetasun hori; hain zuzen ere, Zolloko galdetegiko adibideak dira inguru hartako zaharrenak; izan ere, aldaera zaharrak nagusi diren arren ( $3 \mathrm{r}$ aurrean, $3 \mathrm{r} \& 3 \mathrm{v}$ echea, $3 \mathrm{r}$ sanean, $3 \mathrm{v}$ urtean, $3 \mathrm{v}$ echean, 3v \& 4r (birritan) poderean, 4r semeari, 4r \& 4v partea, $4 \mathrm{r}$ ostean, $4 \mathrm{r}$ bereac), badaude bokal-igotzearen adibideak ere: $3 \mathrm{r}$ dirian, $3 \mathrm{v}$ oiacas, $4 \mathrm{r}$ siriala, $4 \mathrm{r}$ ereitietan, 4r ensutia, 4r badauquie.

6.2.3. Gaur egun, aurreko berrikuntzaren hedadura bat dator, oro har, $i+V^{(a, e, o)}$ $>i j V^{(a, e, o)}$ kontsonante epentetikoak Bizkai sartaldean duen hedadurarekin; izan ere, ibar gehienak gordetzaile dira (ez dago halako epentesirik Uribe Kostan, Txorierrin, Arratian, Zeberion, Orozkon, Nerbioi ibarraren hegoaldean eta Mungia aldeko auzo gehienetan), baina sistematikoa da Nerbioi ibarraren iparraldean eta Bilbo hegoaldeko auzoetan. Aurreko ezaugarriari buruz esandakoarekin bat, kasu honetan ere egoera bertsua ageri da XVIII-XIX. mendeetako testuetan, eta Zolloko galdetegikoak dira Bizkai sartaldeko adibide zaharrenak: $4 \mathrm{r}$ ausiyatan, $4 \mathrm{r}$ erdiya, $4 \mathrm{v}$ echiyac, $4 \mathrm{v}$ gustiya eta $4 \mathrm{v}$ gustiyac. Halere, testuan gehiago dira salbuespenak: $3 \mathrm{r}$ gustiai, $3 \mathrm{r}$ ausia (eta $3 \mathrm{r}$ au ausiau), 3r viac, 3r \& 4r gustiac, 3r daiensat, 3r \& 3v (birritan) \& 4r (lautan) \& 4v Badaquie, 3v erdiac, 3v gustioc, 3v ynbentarioric eta abar.

6.2.4. Beste alde batetik, Bizkaian gaur egun ezohiko den $u+V^{(a, e, o)}>u b V^{(a, e, o)}$ epentesi kontsonantikoaren adibide bat dago Zolloko galdetegian: $3 \mathrm{v}$ artuben. Ez dago beste adibiderik testu osoan eta esparru juridikoko hitz tekniko jakin batean agertzen denez, pentsa liteke ez dela tokiko hizkerakoa, ezpada beste nonbait ikasia; nolanahi ere den, ez da guztiz harrigarria XVIII. mendearen amaieran Bilbo aldean halako epentesiaren arrastoa aurkitzea, Nerbioi ibarraren iparraldeko sermoilarien lanetan ere agertzen baita (Zuloaga, 2013, $\mathbb{\$} 4.8$ ).

6.2.5. Mitxelenak (1961, 51. or.) aipatu bezala, Bizkaiko hego-mendebalean agertzen da lehenengoz beheko bokalaren asimilazioa $\left(a \rightarrow e /\left\{{ }_{1}^{i}{ }_{\mathrm{u}}\right\}(\mathrm{C}) \_\right)$edo De Rijk-ek (1970) $R u i$ deitutako araua; are gehiago, Viva Jesus delako testuan (ca. 1640, apud Ulibarri, 2009, 2010) hurrengo bi mendeetako beste edozein testutan baino indartsuago agertzen da (Zuloaga, 2017). Bada, Zolloko galdetegian ere badaude zenbait adibide, nahiz eta mende bat lehenagoko Viva Jesus-en eta are Orozkoko 1739ko otoitzetan baino ahulago agertu. Zehazki, honako testuinguru hauetan aurkitu dugu:

(a) Hitz-erroan, nahiz eta adibideak oso gutxi izan: 3r libreu eta $4 \mathrm{v}$ facultederic aurkitu ditugu. Gainerako hitzen erroetan beheko bokala ez da ixten: 3r Dirause, 3r obispadu, 3r \& 4v pregunta, 3v isan, 3v estimasiño, 3v sugateco, 4r gurasoac, $4 \mathrm{r}$ ajustau, $4 \mathrm{v}$ libradu, $4 \mathrm{v}$ censura. iz > (i)x palatalizazioaren ondotik ere ez da asimilaziorik ageri: $3 \mathrm{r}$ elesate, $4 \mathrm{v}$ elesa.

(b) Izenaren inflexioan ez dago - $a$ artikulu definitu mugatu asimilaziodun bakar bat ere ez hitz amaieran, ez beste bokal baten aurretik, bokal itxia jatorrizkoa 
zein bigarrenkaria izan: 3r ausia, $3 \mathrm{r}$ articuladua, 4r costura, 4r gasstua, 4r urdaia, 4r ensutia, 4r erdiya, 4v gustiya; 3r gustiai, 4r eurai. Pluraleko -ak edo beste deklinabide-marka baten hasierako kontsonantea dagoen gehienetan ere ez dago asimilaziorik: 3r viac, 3r \& 3v gustiac, 3v erdiac, 4v gustiyac, 4v echiyac, $4 \mathrm{v}$ ichiac; $3 \mathrm{r}$ gausaric; $3 \mathrm{r}$ contratuan, $3 \mathrm{v}$ abustuan $4 \mathrm{r}$ ausiyatan; $3 \mathrm{v}$ oiacas, $3 \mathrm{v}$ tresneriagas, $4 \mathrm{r}$ cesinagas. Artikulu asimilaziodunen bat agertzen $\mathrm{da}$ absolutibo pluralean eta inesiboan: $3 \mathrm{v}$ cumpliduec, $3 \mathrm{v}$ aprobechamintuen. $4 \mathrm{r}$ Goirigas soziatibo singularrean ez dago disimilaziorik. Bestalde, bakarra izanagatik, interesgarri da 4v eta alan prebenietan yaque daquianay ('dakitenei'), hiperzuzenketa baitirudi.

(c) Adizkietan ageri da beste inon baino sarriago Rui araua; zehazki, erlatiboko menderagailuan (3r eguin deusen), -(a)la menderagailuan ( $3 \mathrm{v}$ isan situsela, $4 \mathrm{r}$ egon siriela, $4 \mathrm{r}$ gobernau diriela ${ }^{21}$, $4 v$ erresibidu situsela, $4 \mathrm{v}$ bereac balisela, $4 \mathrm{v}$ saldu eudesela) eta eduki edugi-ko - $k a$ - elementuan: $3 \mathrm{v}$ dauquesala. Dena den, adizkietan asimilaziorik gabekoak dira adibide gehienak: $3 \mathrm{r}$ (birritan) daucala, 3v daucasala, $3 \mathrm{v}$ echi situsala, $4 \mathrm{r}$ daucala, $4 \mathrm{r}$ erein siriala; $3 \mathrm{r}$ eguin ditusanacas, $3 \mathrm{r}$ seinsuc dirian, $4 \mathrm{r}$ eche situsanacas, $4 \mathrm{r}$ aguindu eusasan; $4 \mathrm{r}$ eucan.

Analogiaz sortua bide da $3 \mathrm{r}$ señetan dagosen erlatiboko menderagailuko aldaera, adizki horretan ez baitago beheko bokala asimilatzeko ingurune egokirik.

Aurreko testuinguruetatik kanpo, eratorpen-atzizkiek ez dute asimilaziorik: $3 \mathrm{v}$ bigarrenagas, $3 \mathrm{v}$ amasorcigarreneguino, $4 \mathrm{r}$ laugarren. $4 \mathrm{v}$ adisquide- $\mathrm{n}$ egon liteke (adiskide $>$ adiskida > adiskide), baina ez du zertan, adiskide aldaera nagusi baita mendebaleko testu zaharretan (OEH, s. v. adiskide). Halaber, ondoz ondoko hitzen artean eta klitikoetan asimilaziorik gabeak dira aldaerak, baita lexikalizatutako formetan ere: $3 \mathrm{v} \&$ 3r baita, 4v baita; 3v \& 4r sein dan, 3v bisi san, 4 sein san; 3r libreu daiensat; 3r au, ausiau.

\subsection{Izenaren morfologia}

6.3.1. Euskal Herri zabaleko hizkera gehienetan artikulu hurbilak galtzeko joeraren aurrean, mendebaleko euskarak berritzaile jokatu zuen, gutxienez, XVII. mendearen erdialdeaz geroztik; izan ere, orduan agertzen da testuetan lehenengoz gaur egunera arte zabal iraun duen [erakuslea + izen-sintagma +-aul-oril-ok] egitura pleonastikoa (Martínez-Areta, 2013, 295-296. or.). Are gehiago, orotara gutxi izan arren, adibideak daude bai Bizkaiko hego-mendebalean (Viva Jesus), bai Durango aldean (Kapanaga), berrikuntza 1650 erako Bizkai sartaldean zein sortaldean hedatua zela erakutsiz. Espero zitekeenez, denboran aurrera egin ahala ugaritu egiten dira egituraren adibideak, eta Zolloko galdetegiak adibide argi bana du singularrean eta pluralean: $3 \mathrm{r}$ au ausiau, $3 \mathrm{v}$ onei[c] ondasun gustioc.

21 Bi kasu horietan bigarrenkaria da asimilazioa eragin duen bokala $(i e<i a<e a<a a)$. Ingurune berberean beste horrenbeste gertatzen da asimilaziorik gabeko $4 \mathrm{r}$ erein siriala eta $3 \mathrm{r}$ seinsuc dirian formekin. 
6.3.2. Dotrinazko sermoitegi-ko 2-96 arboleatan, 38-82 aflicciñoeatan, 7-11 \& 7-171 \& 15-30 egunatan, 38-136 estucuseatan zein 13-19 meseatan aldaerak aztergai zituela, «atan erakusle urrunaren inesiboa hizkera honetan artikulu urrunaren (-an) ordez erabiltzen hasia zela» azaldu zuen Ulibarrik (2015, 170. or.), eta ematen du azalpen horren bidez azaltzen dela errazen Zolloko galdetegiko 4r ausiyatan 'auzian' ere. Aldez aurretik aipatutako auzi bat da hizpide pasarte horretan, eta horrek erakuslea irakurtzera eraman gaitzake ( $c f r$. Himmelmann, 2001, $\mathbb{} 2$ eta 3); alabaina, epentesiak artikulua bermatzen du.

6.3.3. Mendebaleko zenbait hizkeratan ee bikoitza dago erakusle pluraletan (boneek, horreek) Euskara Zaharraz geroztik, nahiz eta erabilera orokorra ez izan. Bestalde, badakigu ee bikoitza ei bihurtu dela zenbaitetan, eta hori da, hain zuzen ere, gaur egun Bizkaiko hego-mendebalean entzuten den aldaera arruntetako bat, Zolloko galdetegiak ere badakarrena: 3v onei[c], 3r \& 4r \& 4v (hirutan) oneic.

6.3.4. Zolloko testua irakurrita, arreta ematen du mugagabearen erabilerak, azalbide garbikoa eta beste testu batzuen bidez ezaguna izan arren, garai zaharragoetako lekukotasunak baitakarzkigu gogora. Alde batetik, jatorria adierazten duten artikulurik gabeko erlazio-atzizkiak daude: 3v Andres Arbideco; 3r Dominga Salazarrecoc, 3v (birritan) Domingo Arbidecoc, 3v Don Melchor Ochoa Ysusicogan. Beste alde batetik, ahaidetasun-harremanei lotutako emazte eta aitobe beti dira mugagabe, testuan erreferente bakarrekoak baitira: $4 \mathrm{r}$ daucala bere poderean bere emastec, $4 \mathrm{v}$ errezibidu situsela Domingo de Arbide ta bere emastec, 4r Juan de Ypiñazarrec, Andresen aitobec, aguindu e[u]sela (cfr. garai eta eremu bertsuan Sarriaren adibide hau: 18 Enzun dot zeure emastegaz euqui dozun conversacino ona, 23 Aric egun guichi barru agartu yacan vere emasteri).

6.3.5. Genitiboari dagokionez, Zolloko galdetegiak Lehen Euskara Modernoa baino lehenagoko tradizioarekin egiten du bat, singularrean - $r$ - gabeko aldaerak besterik ez baitaude (cfr. Castaños, 1957): ez dago garaiko zenbait idazle ikasik bultzatutako -aren aldaera osoagoaren arrastorik (Urgell, 2018, 620. or.). Testuan, zehazki, -en eta -an agertzen dira hitz amaieran - $a$ ez bestelako bokalak dituzten genitibo singularretan: 3r \& 4v jaunen 'jaunaren', 3r corregidoren 'korrejidorearen', 4r gustien 'guztiaren', $4 \mathrm{r}$ hacienden 'aziendaren', 4v nagusian 'nagusiaren', 4v abustuan 'abuztuaren'. Azken bi kasuetan gogora datorkigu Arabako hainbat testutako -an aldaera (cfr. garai bertsuko Dotrinazko sermoitegi-ko 23-37 profetean, 28-48 principean eta 38119 camaran, apud Ulibarri, 2015, 162. or.), baina aintzat hartzekoa da gaur egun -an aldaera nagusi dela Bizkaiko hego-mendebalean (Etxebarria, 1991, 115. or. eta hurrengoak; Arretxe, 1994, 199-200. or.; Salazar, 2001, 44. or.; Gaminde, 2007, 112. or.).

6.3.6. Datibo-markak direla eta, Bizkaiko tradizioari eta garaiari dagozkionak agertzen dira Zolloko galdetegian. Alde batetik, singularrean -ari dago (4r bere semeari), eta pluralean -ai (3r abade eta cura jaun gustiai, $4 \mathrm{r}$ tocau bagaric eurai, $4 \mathrm{v}$ prebenietan yaque daquianay). Beste alde batetik, - $i$ zaharraren eta -eri berri(ago)aren arteko lehian nagusitua zen bigarrena: $4 \mathrm{r}$ oneri bere gurasoac eguin eusen 
donaciño-gaiti, 4r aguindu e[u]sela oneri bey bi ta secor bat, $4 \mathrm{v}$ emon bagaric iñosco denporan Andreseri.

6.3.7. Soziatiboaren esparruan ez dago ezustekorik: -gaz \& -akaz dira kasu-markak, Bizkai sartaldean eta erdialdean legetxez, oro har, XVIII. mendearen amaierara arte (Zuloaga, 2015): 3r Dominga de Salazarregas, 3r Domingo de Arbidegas, 3v emaste bigarrenagas, 3v motibu onegas, 4r tresneriagas, 4r urdaia eta cesinagas, 4r Domingo de Goirigas, 4r Andresegas; 3r eguin ditusanacas, 3v oiacas, 3v cashacas, 4r echi situsanacas.

Bestalde, mendebalean soziatiboaren eta instrumentalaren artean lehenengoaren alde gertatutako sinkretismoaren adibideak ditugu (bien arteko harremanen bilakabide diakronikoaz, begiratu Igartua \& Santazilia, 2013): 4r componietan sala urdaia eta cesinagas (gazt. 1v se compuso de tocino, cecina y granos que dexó el sobre dicho), 4v emon bagaric iñosco denporan Andreseri lecuric balietaco mandoagas (gazt. 1v y se balieron tambien de una mula hasta que murió sin que hubiesen permitido al menzionado Andrés que se valiese de ella en tiempo alguno).

6.3.8. Leku-kasuei helduta, testuak egoera modernoa islatzen du ablatiboan. Alde batetik, ez dago -rean zaharraren arrastorik (ezta -reanik-ena ere), eta, espero zitekeenez (cfr. Lakarra, 1984), ablatiboaren eta prosekutiboaren arteko nahastea islatzen dute ondoz ondo ageri diren $4 \mathrm{v}$ aurretic eta $4 \mathrm{v}$ aurreti aldaerek. Gogoan hartzekoa da -ti formalki arrunta dela Bizkai sartaldeko hainbat hizkeratan, hala nola Nerbioi ibarrekoan. Aurrekoari lotuta, motibatiboan -gaiti aldaera agertzen da testuan: $3 \mathrm{v}$ donaciñn-gaiti. Beste alde batetik, -rik atzizkia harik hona esapidean fosildurik besterik ez da agertzen: 3 aric ona 'handik, ordutik hona'.

6.3.9. Muga-adlatiboko -giño aldaerak eremu txikia du gaur egungo Bizkaian: Nerbioi ibarrean dirau inon baino indartsuago, nahiz eta Hego Uribeko beste hizkera batzuetan ere entzun daitekeen eta Bizkaiko testu arkaikoetan sartaldean zein sortaldean agertzen den (Gaminde, 2007, 120. or.). Zolloko galdetegian ere agertzen da, denbora adierazteko: lehenik, 3v abustuan amasorcigarreneguino adibidean; bigarrenik, 3v artiño adibidean, higaturik eta arte posposizioari lotuta $(<$ artegino, Añibarrok erabili bezala; cfr. OEH, s. v. arte).

6.3.10. Gaztelaniazko -ión amaiera ez da beti eta leku guztietan berdin egokitu, garaia eta eremua zein den. Mendebaleko testuetan -ĩ̃o, -iñoe eta -iño (Mitxelena, 1961, 122. or.) aldaerak agertzen dira: lehenbizikoa testu zaharrenetan eta ondokoak Euskara Arkaikoaz geroztikoetan. Bizkaiko mendebalari dagokionez, egun ez dago -iñoe-rik (sistematikoa da -iño), baina Viva Jesus-eko, Mikoletaren eskuizkribuko zein Sarriaren sermoietako adibideek bermatzen dute, besteak beste, eremu hartan ere ezagun izan zela garai batean. Bada, Zolloko galdetegia horietatik guztietatik aldentzen da, eta egungo egoerarekin egiten du batago, -iño baitago gehienetan: 3r errelaciñoa, 3r ynformaciñoetara, 3v estimasiño, 4r donaciño-gaiti, 4v excomuniño. Aurrekoekin batera $4 \mathrm{v}$ obligacio ere badago, baina garaia eta gainerako adibideak ikusita ez dugu uste bokal sudurkaria proposatu behar denik: idazlearen akatsa izan daiteke, gaztelaniazko 
obligación-en eraginez emandako forma, edo erdialderagoko ereduren batetik hartutakoa $(\mathbb{S} 6.4 .3)$.

6.3.11. Mitxelenak (1955, 86. or.) Betolatzaren dotrinan proposatutako aldaketak aldaketa, gaur egun badakigu Arabako ipar-mendebalean eta Bizkaiko hego-mendebalean gaztelaniazko -miento diptongoduna -mientu eta -mintu bihurtu zela. Horren adibideak daude Viva Jesus zaharrean, Dotrinazko sermoitegia-n (Ulibarri, 2015, 153. or.) eta XVIII. eta XIX. mendeetako Nerbioi ibarreko sermoilarien lanetan, bai eta XIX. mendean Bonaparte printzearen egitasmorako bildutako lanetan ere (Zuloaga, 2013, 603. or.). Zolloko galdetegiak bat egiten du aurrekoekin, 3v aprobechamintuen baitakar.

\subsection{Aditzaren morfologia}

6.4.1. Euskal testuak arakatuta posible da partizipioetako -rik eta - $t a$ atzizkien arteko lehia berreraikitzea: Urgellek (2001, xcv. or.) azaldu bezala, -ta berrikuntzaren hedapena da, funtsean, denborak aurrera egin ahala gertatutakoa; orain, begiratu Mounole (2018) laneko azterketa zehatza.

Zolloko galdetegian ez dugu -ta bakar bat ere aurkitu: [-rik egon] eta [-rik eduki] perifrasiak agertzen dira, hurrenez hurren: $3 \mathrm{r}$ dagosanac yfiniric, $3 \mathrm{r}$ daucasala gorderic. Bestalde, -rik partizipioa baliatzen da adberbioa eratzeko perpaus honetan: $3 \mathrm{v}$ echi situsala elesa onetaco basoetan secor bi, eta bera bisi san echean ondo conponiduric.

6.4.2. Mendebal gehienean $-n$ atzizkia erantsi ohi zaie moduzko adberbioei, esanguraren indargarri (Zuazo, 2014, 174. or.), eta hortik sortu dira nolan, zelan edo apurkan bezalako aldaerak. Hain zuzen ere, erabilera-maiztasunagatik hala egungo hizkeretan nola aurreko mendeetako testuen corpusetan galdetzaileei lotuta agertzen da beste inon baino ugariago - $n$, eta horrela da Zolloko galdetegian ere: $3 \mathrm{r} \& 3 \mathrm{v} \& 4 \mathrm{r}$ selan. Nolanahi ere den, $4 \mathrm{v}$ alan 'hala' ere badago.

6.4.3. Zolloko galdetegian aditz-izenak eratzeko hiru atzizki erabiltzen dira: -te, -eta eta -tze. Testuaren luzera dela eta, batzuen eta bestetzuen adibideak ez dira ugariak, baina funtsean Bizkai sartaldean XVIII. mendean espero zitezkeen formak dira, -tze-ren kasuan izan ezik.

Lehenik, -te zaharra agertzen da 3v ynportateuan mailegu modernoan, atzizkiak garai zaharragoetan zituen murriztapenetatik aske; begiratu Urgell $(2006, \mathbb{S} 2.1 .2$ eta \$2.1.8).

Bigarrenik, Mendebalean Euskara Zaharraz geroztik hainbeste hedatutako -eta agertzen da; beste edozein atzizki baino ugariagoa da testuan, eta $-a(d) u$ eta $-i d u$ oinarri duten aditz mailegatu modernoetan agertzen da sarrien: $3 r$ \& $4 \mathrm{r}$ toquetan, 4r componietan, $4 \mathrm{r}$ gozetan, $4 \mathrm{v}$ prevenietan, $4 \mathrm{v}$ balietaco. 
Hirugarrenik, -tze atzizkia agertzen da $4 \mathrm{v}$ declarasera forman. Gogoratzekoa da, nahiz eta Euskara Zaharraz geroztik -eta-ren mesedetan lekua galdu, -tze ez dela atzizki ezezaguna Mendebalean (Urgell, 2006); are gehiago, zenbait hizkeratan oraindik erabiltzen da CVC-TU egiturako adizkietan aditz-izenak eratzeko (sartzean, hartzean eta abar). Besterik da Zolloko galdetegiko $4 \mathrm{v}$ declarasera adibidea, ez baitirudi hain arrunta: mailegu modernoa da, eta deklarau bide da oinarria; beraz, bai garaiko, bai osteko lekukotasunen argitan, errazago espero zitekeen deklaretan aldaera (adlatibo-markaz, begiratu $\mathbb{6}$ 6.5.4), eta ez dugu baztertzen idazleak erdialderagoko testu- edo hizkeraereduren bat baliatu izana pasarte hau prestatzean ( $c f r$. arestian aipatutako obligacio, testuko gainerako -ziño guztien aurka).

6.4.4. "edun aditz laguntzaile iragankorraren hirugarren pertsona pluraletan ergatiboak bi alomorfo ditu Bizkaiko euskaran, testu zaharretan zein gaur egungo hizkeretan: -de (daude) eta -e (dabe) ${ }^{22}$. Ematen du lehenengoa Bizkaiko sartaldean gordetako arkaismoa dela ( $c f r$. Trask, 1995, 231. or. eta Lakarra, 2013, 293. or.).

Zolloko galdetegiari dagokionez, bat egiten du Bizkai sartaldeko tradizioarekin, -de alomorfo zaharra baitute adizkiek: 4v saldu eudesela, 4v balio eta saldu eudela.

6.4.5. Arabako, Bizkaiko eta Gipuzkoa hegoaldeko zenbait testutan eban > eben 'zuen' aldaera asimilazioduna arrunta da *edun aditz laguntzailearen 3. pertsona singularrara adierazteko (Altuna, 1995). Bizkai sartaldeari dagokionez, Lehen Euskara Modernoaren sasoian Astigarraga basauriarraren sermoietan badaude halakoak, bai eta Uriartek Bonaparterentzat prestaturiko Orozkoko dotrinan ere (Zuloaga, 2013, $\mathbb{S} 4.5)$.

Zolloko galdetegian badago aldaera asimilaziodunik, nahiz eta bakar ez izan: 4r Domingoc erosi euen lanoñeco bat da adibide garbiena, eta aurkako bakarra $3 \mathrm{v}$ seinbat ynportateuan asimilaziobakoa da. Bestalde, eula 'zuela' adizkia birritan agertzen da, eta pentsatzekoa da asimilazio-kate baten azken emaitza dela: euala > euela > eula. Hona hemen testuko bi adibideak: 3r Dominga Salazarrecoc escondu sanean Domingo de Arbidegas es eula beste gausaric eroan, 3v Domingo Arbidecoc bere emaste bigarrenagas batera gosadu eula Echachuco echea.

6.4.6. Bizkaiera zaharrean egin-en erroko adizkietan bipertsonal (-a-) eta hirupertsonal (-e-) bereizketa Lehenengo Euskara Modernoan galdu bide zen; zehazki, XVIII. mendearen amaieraz geroztik galeraren zentzu nabarmenak daude ( $c f r$. Irigoien, 1958; Lakarra, 1986). Zolloko galdetegiari dagokionez, adizki bakarra dago eta erkagairik ezak ez du aukerarik ematen oposizioa zertan zen erabakitzeko; nolanahi ere den, adizkia bipertsonala da, eta - $a$ - du: 3r libreu daiensat.

22 *edun-en adizkiez ari banaiz ere, aintzat hartzekoa da - del-tel-e aldaeretan zaharrena -de dela eta inoiz Euskal Herri osoan orokor izan zela (cfr. egon-eko daude); are gehiago, beste adizki batzuetako adibideak aurki daitezke Bizkaiko bertako testu arkaiko eta zaharretan; cfr. Egiaren kantako ecardeçan (birritan). 
6.4.7. Mitxelenak (1981, 527. or.) hiperbizkaiera deitutakoa deskribatzeko ezaugarrien artean leku nabarmena izan dute adizkiek: «Honela bizkaiera "jatortzat" gintzazan, dauz, ebazan, eitean eta beste eman ohi dira nahiz eta guzti horiek berrikuntzak izan gainerako euskalkietarik hurbilago eta bizkaierazko testuetan askozaz zaharrago eta ugariago diren ginean, ditu(z), zituztan eta zidinen aurrean» zioen Lakarrak (1986, 670. or.), lehenengo adizkiak XIX. mendearen erdialdeaz geroztik hedatu baitziren.

Zolloko galdetegia dela eta, adibideak ez dira asko eta denak dagozkie hirugarren pertsonari, baina agertzen diren guztiak pleonastikoak dira, -it- eta $-z$ pluralgileak baitituzte: $3 \mathrm{r}$ ditusanacas, $3 \mathrm{v}$ situsala, $3 \mathrm{v} \& 4 \mathrm{v}$ situsela, $4 \mathrm{r}$ situsanacas, $4 \mathrm{v}$ ditus, $4 \mathrm{v}$ situesala.

6.4.8. Hirugarren pertsonako -e pluralgilea birritan ezarria duten adizkietan disimilazioa zein asimilazioa gertatu da Mendebalean, hizkera zein den: zagozee 'zaudete' > zagozie zein zagoze bihurtu da. Nerbioi ibarrari dagokionez, disimilazioa nagusi da bai gaur egun, bai XIX. mendeko testuetan, eta emaitza berori agertzen da Zolloko galdetegiko adibide batean: 4 badauquie 'badaukate'.

6.4.9. Helburuzko perpausak eratzeko, Euskara Arkaikoaz geroztik euskalki gehienetan da ezagun -tzat destinatiboko markaren erabilera; hain zuzen ere, subjuntiboko laguntzaileei gehitu ohi zaie eta erabilera horrek XX. mendearen hasierara arte iraun zuen Bizkai sartaldean Azkueren (1925, $\mathbb{S} 560$ ) arabera. Bada, aurreko mendeetako testuetan ere ugari agertzen da egitura (Ros, 2004), eta Zolloko galdetegian badago adibide bat: 3r Echachuco echea libreu daiensat 'Etxatxuko etxea libratu dezaten'.

6.4.10. Bizkaiko euskara arkaiko eta zaharrean eta Dotrinazko sermoitegia-n behin baino gehiagotan agertzen da $z e$ 'ez' partikula, eta badirudi jaurerriaren sartaldean gramatikalizaturik iraun duela ze din > zein ezezko partikularen barnean (cfr. Ulibarri, 2015, 296 eta 360. or.). Bizkaian, Astigarraga basauriarrak seguisue onetan ifini eta deadar eguin cedaguien bezalakoak dakartza, eta Basaurin jasoak ditugu sein loitu 'ez dadin lohitu' eta seiñ estie lar bete 'ez dadin hestea lar bete'. Zolloko galdetegia dela eta, $3 \mathrm{v}$ jaquin sein din seinbat ynportateuan 'jakin ez dadin zenbat inporta zuen' pleonastikoa agertzen da: gramatikalizazio-prozesuaren ondorioz egileak partikula oso eta beregaintzat jo bide zuen zein, “edin osagaia identifikatu barik.

6.4.11. Bizkaiko hainbat hizkeratan gertatu da -au- > -eu- > -e- bilakabidea (Zuazo, 2014, 166-167. or.) eduki-ren forma jokatuetan, eta, horrenbestez, gero eta gutxiago dira jatorrizko - au-ri eutsi dioten hizkerak. Dakigula, Viva Jesus-ekoak dira -au- >-eualdaketaren lehenengo adibideak Mendebalean (Ulibarri, 2010, 63. or.), eta Nerbioi ibarraren iparraldean XVIII. mendearen amaieran agertzen dira, gerora ezagutu dugun banaketarekin bat etorriz (Zuloaga, 2013, $\mathbb{S} 4.2$ ). Ibarraren hegoaldeak eta Zeberioko eta Orozkoko hizkerek, aldiz, gordetzaile jokatu izan dute, -au-ri eutsiz. Kasu honetan Zolloko galdetegia gordetzailea da: $3 \mathrm{r} \& 4 \mathrm{r}$ daucala, $3 \mathrm{r} \& 4 \mathrm{r}$ daucasala, $3 \mathrm{v}$ dauquesala, $4 \mathrm{r}$ badauquie, $4 \mathrm{v}$ danquela. 


\subsection{Sintaxia}

6.5.1. Pertsona-izen berezietan, jatorria adierazten duen -ko eskuinean agertzen da sistematikoki, adjektibo funtzioa baitu (cfr. Krajewska, 2017, $\mathbb{} 4$ eta 2019): 3r Dominga Salazarrecoc, 3v Domingo Arbidecoc, 3v Andres Arbideco, 3v Domingo Arbidecoc, 3v Don Melchor Ochoa Ysusicogan.

6.5.2. Hainbat euskalkitako tradizioarekin bat, perpaus erlatiboak hainbatetan eraikitzen dira izenordain galdetzaileak erabilita, «eredu erromaniko»-tzat jo izan diren egiturak sortuaz (orain, ustezko eredu mailegatu horretaz, begiratu Krajewska, 2017). Bestalde, Mendebaleko erabilera modernoekin bat eginez, -an da menderagailua: $3 \mathrm{r}$ presentau dauela bere articuladua, seiñetan dagosen pregunta oneic; $3 \mathrm{r}$ bere usuco erropac, seinsuc dirian dagosanac yfiniric contratuan; $3 \mathrm{v}$ eta guero abustuan amasorcigarreneguino, sein dan aurtengo urtean sei urte cumpliduec; $4 \mathrm{r}$ Josepha de Arbiden senarrag[a]s, sein san oneri bere gurasoac eguin eusen donaciño-gaiti.

6.5.3. Mendebaleko tradizioari jarraituta, $b i$ zenbatzailea izen-sintagmaren eskuinean agertzen da sistematikoki: $3 \mathrm{v}$ bere emaste bigarrenagas, $3 \mathrm{v}$ echi situsala elesa onetaco basoetan secor bi, $4 \mathrm{r}$ bey bi ta secor bat.

6.5.4. Gaur egun Mendebalean (Zuazo, 2017, 53. or.) helburuzko perpausetan aditzizenaren markari inesiboa gehitu ohi bazaio ere, erabileraren sistematikotasuna eta hedadura ez da berbera aurreko mendeetan; izan ere, Erdialdeko eta Ekialdeko iturrietan bezala, Mendebalekoetan ere aurki daiteke adlatiboaren gainean eraikitako perpausik. Zolloko galdetegiak $4 \mathrm{v}$ declarasera dakar behin, baina aditz-izeneko -tze hori susmopean dugu ( $\$$ 6.4.3), ez baita ohikoa Mendebalean XVIII. mendean, eta izan liteke erdialderagoko testu-ereduren batetik hartu izana forma osoa; hartara, kasu honetako adlatiboa ere beste hizkeraren batetik mailegatua izan liteke, nahiz eta Nerbioi ibarreko beste sermoilari batzuen lanetan egon badagoen: Sarria 2 gausa chiquerrenac vere isilic artutera; Astigarraga 8 guasan oran icustera.

6.5.5. Euskal gramatikarien artean aspaldirik da ezagun Bizkaiko, Arabako eta Gipuzkoako zenbait testu eta hizkeratan osagarri zuzenarekiko komunztadura falta dela (Lakarra, 1986, $\mathbb{S} 5.21$ eta 1996, 188-190. or.); hots, hainbat kasutan objektu zuzena plurala izan arren, aditzean plural hori ez dela islatzen. Bada, Zolloko galdetegian komunztadura faltaren bi adibide aurkitu ditugu. Honakook dira adibideak: 4r Badaquie Juan de Ypiñazarrec, Andresen aitobec, aguindu e[u]sela oneri bey bi ta secor bat; $4 \mathrm{v}$ Badaqui[e] lo mismo balio eta saldu eudela amasorsi auns Simona de Ypiñasarrec echiyac. Edizioan aurrekoak zuzentzeke utzi baditugu ere, gogoan hartzekoa da 3v-95 oharrean adierazitakoa; hots, idazleak echi situa-idatzi ondoren zuzendu eta plurala ezarri zuela. Idazleak/itzultzaileak komunztaduraren ezagutza zuela islatzen du horrek, nahiz eta besterik den erabakitzea bere hizkeran komunztadura falta arrunta zen eta berak idatziz zuzendu nahi izan zuen ala idatzi ahala ihes egindako komunztaduraakatsak diren. 


\subsection{Lexikoa}

6.6.1. Hiztegiaren esparruan, sintaxiarenean legetxez, testuak ez du aipagarri berezi askorik testu-generoak berak dakartzan eremu semantikoetatik eta zenbait aldaera dialektalek eta lokalek izan dezaketen interesetik harago.

6.6.1.1. Lehenengoak direla eta, testu juridiko-administratiboa izanik, interesgarri dira bertan agertzen diren eremu horretako berba-esapideak, halakoek zer-nolako tradizioa izan duten irudikatzen laguntzen baitute. Esparru horri hertsiago edo zabalago loturik agertzen dira $3 \mathrm{r}$ articuladu, $3 \mathrm{r}$ artuben, $3 \mathrm{r}$ errelaciñoa, $3 \mathrm{r}$ elesate, $3 \mathrm{r}$ (birritan) $\& 4 \mathrm{r}$ ausi, $4 \mathrm{r}$ ausiyatan, 4v declarasera, $4 \mathrm{r}$ donaciño, $4 \mathrm{r}$ ajustau 'konpondu, adostu', 4v facultederic, $3 \mathrm{v}$ gosadu, $4 \mathrm{r}$ gozetan, $4 \mathrm{v}$ gozemenenac, $3 \mathrm{r}$ contratuan, $3 \mathrm{r}$ corregidoren, 3r matrimoñiatura, 3v (birritan) ondasun, $4 \mathrm{v}$ prebenietan, $3 \mathrm{r} \& 4 \mathrm{v}$ provisore zein $4 \mathrm{v}$ censura.

6.6.1.2. Bestalde, baserriko eta landa-giroko bizimoduari lotutako hainbat berba agertzen dira, hala nola animalien izenak (4v auns, $4 \mathrm{r}$ acienda, $4 \mathrm{r}$ acienden, $4 \mathrm{r}$ bey, $4 \mathrm{r}$ lauoñeco, $4 \mathrm{v}$ mando, $4 \mathrm{v}$ mandoagas, $3 \mathrm{v} \& 4 \mathrm{r}$ secor), aurkintza eta landarediari lotuak (4r arto, $4 \mathrm{r}$ artoac, $3 \mathrm{v}$ basoetan, $3 \mathrm{r}$ erri, $4 \mathrm{v}$ pago, $4 \mathrm{r}$ solo), lan, etxeko tresna eta lanabesei lotuak ( $3 \mathrm{r}$ cashetan, 3v cashacas, $4 \mathrm{r}$ erein, $4 \mathrm{r}$ ereitietan, $4 \mathrm{v}$ gabi, $4 \mathrm{r}$ tresneriagas) eta jatekoen ingurukoak (4r cesinagas, 4r urdaia).

6.6.1.3. Lexiko eta aldaera dialektalei dagokienez, Zolloko testuak ez dakar ezusteko handirik, eta bat egiten du Mendebalean espero zitekeenarekin. Berba eta aldaera arruntak dira Mendebalean 3r abade, 3v baga eta 4r \& 4v (birritan) bagaric, 3v demporan eta 4v denporan, 4v \& 4r emonic, 3r eroan, 4v iñosco 'inoizko', 4v ychiac 'utziak', $4 \mathrm{v}$ legues 'bezala', $4 \mathrm{r}$ ostean 'ondoren', $4 \mathrm{r}$ soloco 'soroko', 4r urten 'irten', 3v seinbat 'zenbat', 3r seinsuc 'zeintzuk' eta 3r \& 3v \& 4r selan.

Aurrekoekin batera, aipatzekoak dira entzutea eduki esamoldea 'zerbaiten berri izan' (4r ensutia badauquie) eta 4v emeco 'hemengo' aldaera, bizkaitar idazleen artean ezaguna izan arren nagusi ez dena (OEH, s. v. hemengo). Halaber, galdetegiko auzo 'auzoko, bizilagun' ( $3 \mathrm{r}$ elesate onetaco ausoac, $3 \mathrm{r}$ erri onetaco ausoac) aldaera zaharrak bizirik dirau Bizkaiko hainbat hizkeratan.

6.6.1.4. Eremu txikiagoko hitz eta aldaerei dagokienez: etxe aldaera sabaikariduna dago Bizkai sartaldean oro har eta Nerbioi ibarrean zehazki baliatzen ohi den etse aldaera zaharraren partez bai Etxatxu toponimoan, bai izen arruntean (3r \& 3v echea, $3 \mathrm{v}$ echean); nolanahi ere den, egungo erabilerak erabilera, Nerbioi ibarreko aurreko mendeetako idazleen testuetan ere aurki daiteke etxe (cfr. Sarria 1 echietan edo 23 echiori; Astigarraga 1 eche batian, 3 eche orretan).

Hurrengo ataleko hiztegiak erakusten duenez, itxi 'utzi' aldaerarekin batera $(4 \mathrm{v}$ $y$ chiac), Zolloko galdetegian etxi ere badago ( $3 \mathrm{v} \& 4 \mathrm{r}$ echi, $4 \mathrm{v}$ echiyac); beraz, badirudi bi aldaerak lehian zeudela (Bizkaiko hego-sartaldean $e$ - du aditzen batek; cfr. Orozkoko ekosi 'ikusi' aldaera). 
Ahaidetasun-harremanei lotuta, aitobe 'aitaita' aldaera (4r Juan de Ypiñazarrec, Andresen aitobec) Bizkaiko hego-mendebalekotzat jo zuen Azkuek (OEH, s. v. aitobe), eta bertan erabili izan da bai Euskara Zaharrean (ayta-obea eman zuen Mikoletak), bai egungo euskaran: aitue darabilte Arrigorriaga eta Basauri aldeko hiztun zaharrek aitite-rekin batera.

Bestalde, sugate ( $3 \mathrm{v}$ sugateco) Bizkai sartaldeko zenbait hizkeratako sute eta suite-ren aldaera zaharra da (cfr. Landucci 252 sugatea eta Mikoleta $7 \mathrm{r}$ sugatea, nahiz eta Refranes y sentencias-ek 33 suate dakarren), eta kontsonanteari eutsi dio Nerbioi ibarreko gaur egungo euskarak (sugete).

Euskara Batuko ipini formak hainbat aldaera ditu Mendebalean, eta banaketa ñabarra bai kronologian, bai geografian: Lakarrak (2011, 107. or.) "edun-heben-i > "ewhebeni > "efe.ni bilakabidetik azaldu zituen efeni, ibeni, imini eta ipini, eta Zolloko galdetegia hurbilago dago lehenengotik: 3 yfiniric. Halaber, ifini aldaera darabil ugarien Sarria sermoilari etxebarritarrak, eta Azkueren arabera Bizkaiko hego-sartaldean zegoen inon baino indartsuago, nahiz eta imini aldaera ere aurki daitekeen bai testu zaharretan ( $c f r$. Refranes y sentencias-eko 99 imini eta 192 ifini, eta Mikoletaren 8v ymini), bai egungo hizkeretan.

\section{TESTUKO EUSKARAREN KOKAPEN GEOGRAFIKOAZ}

Jatorri ezezaguneko testuen hizkera nongoa den argitzen saiatzen garenean lagungarri izan ohi zaigu informazio estralinguistikoa, hala nola testuan bertan zein paratestuetan aipatzen diren izen propioak eta gertakarien inguruko berriak: toponimo, antroponimo edo leku ezagun batean jazotako gertakari jakin bat aipatzen bada, zentzuzkoa da pentsatzea testuak lotura zuzena duela aipagaiarekin; baina, gogoan izan behar da halako datuak lagungarri direla, eta lagungarri bakarrik: kontuz aritu behar dugu ondorioak ateratzean (McIntosh, Samuel \& Benskin, 1986, $\mathbb{1} 1.5 .3$ ), izen jakin bat agertzeak ez baitakar testuko hizkera nahitaez izenari lotutako ingurukoa izatea: Arrasateko erreketaren kantuetan bergararrok eta Mondragoe aipatzen dira, baina datu linguistikoek erakusten dute kantuetako batzuk Bizkaiko ipar-sartaldean sortu zirela, ez Gipuzkoako sartaldean (Zuloaga, 2011b).

Lan honetan aurkezten dugun testuari dagokionez, Zolloko galdetegi izendapenak berak antzeko ondorioak eragiten ditu, berez: hala aipatu izan da bibliografian (Ros, 2004; Ulibarri, 2015; Zuloaga, 2017), Zolloko bizilagunentzat prestatutako galderasorta biltzen baitu; alabaina, dokumentazio osoa begiratuta badirudi galdetegia Bilboko eskribau Joseph de Aranzazugoitiaren eskribau-etxean prestatu zela, nahiz eta ez dugun erabat ziur esaterik nork prestatu zuen: beharbada Aranzazugoitiak berak, beharbada haren agindupeko eskribau batek. Hartara, testuaren oinarrian ez Zolloko, baina beste eremu bateko (Bilboko?) euskara dagoela pentsa daiteke, nahiz eta horrek ez duen baztertzen, jakina, idazleak bere hizkuntza hartzaileen arabera molda ezin zezakeenik (Bell, 1984, 159. or.). 
Hona iritsita, interesgarri da Bilbotik Zollora bitarteko euskararen arteko loturez aritzea; izan ere, eremu horretako hizkerei buruzko lanek (Yrizar, 2001; Gaminde, 2002; Zuazo, 2017; Zuloaga, 2018) adierazten dute hizkera bera edo oso hurbilekoa erabiltzen dela Bilbo hegoaldeko auzoetan eta Zollon. Are gehiago, hizkera bera erabili izan dute Nerbioi ibarraren iparraldeko herrietan, eta ematen du mendialdeko bizimoduak XX. mendearen bigarren erdira bitartean izandako eragina garrantzitsua izan dela filiazio-gaietarako.

Nerbioi ibarraren iparraldeko euskara, Bilboko hegoaldeko auzoak ere biltzen dituena, berritzailea da zenbait ezaugarritan: Bizkai sartaldeko hizkeretan aurkitzen ez ditugun berrikuntzak agertzen dira beste leku batzuetan gorde ez diren ezaugarriekin batera, nolabaiteko uhartetxoa sortuz. Bada, ibarreko zenbait testu aztertzean erakutsi zenez (Zuloaga, 2010, 2011a eta 2013; Etxazarra, 2012), joera berritzaile horiek agerikoak dira XVIII. mendearen amaieraz geroztik: literatur ereduek eta hizkera-eredu landuek dituzten eraginak eragin, Bizente Sarriaren edo Juan Ignazio Astigarragaren hainbat testuren azpian datzan hizkuntza-eredu «herrikoia» gerora ezagutu dugun hizkeraren aurrekari da.

Galdera da egungo hurbiltasun edo batasun linguistikoa XVIII. mendearen bigarren erdian ere gertatzen ote zen; alegia, Zolloko galdetegiak biltzen duen euskarak bat egiten ote duen Nerbioi ibarraren iparraldeko euskararekin. Egia esatera, Zolloko galdetegiko euskara aztertzean tarteka Nerbioi ibarreko zenbait testurekin eginiko loturek hala iradokitzen dute, baina, ziurtatzeko, arkaismoak baztertu eta zenbait berrikuntzaren hedadura aztertuko dugu, XVIII. mendearen amaierako Bizkaiko hegomendebaleko eta Aiara aldeko zenbait testu alderatuta ${ }^{23}$. Zehazki, Orozkoko 1739ko otoitzak, Aiara aldeko Dotrinazko sermoitegia eta Sarria etxebarritarraren sermoiak alderatu ditugu:

23 Jakina, testu eta egile bakoitzaren hizkerak baditu garaiari, sorlekuari zein sasoian sasoiko literatur hizkuntzaren ereduari lotu eta zehatz aztertu beharreko berezitasunak, baina hemengo helburuetarako ez dirudi beharrezkoa denik ur hain sakonetan sartzea (begiratu Zuloaga, 2011a eta 2011b; Ulibarri, 2008, 2010 eta 2015). 
2. taula. Zolloko galdetegia eta XVIII. mendeko testuak

\begin{tabular}{|c|c|c|c|c|}
\hline Ezaugarria & $\begin{array}{c}\text { Zolloko } \\
\text { galdetegia } \\
(1770)\end{array}$ & $\begin{array}{c}\text { Orozkoko } \\
\text { otoitzak } \\
(1739)\end{array}$ & $\begin{array}{l}\text { Dotr. sermt. } \\
\text { (Aiara, ca. } \\
\text { 1780) }\end{array}$ & $\begin{array}{c}\text { Sarria } \\
\text { (Etxebarri, ca. } \\
\text { 1790-1804) }\end{array}$ \\
\hline$e \rightarrow i_{-} V^{(a, e, o)}$ & + & - & $+/-24$ & + \\
\hline$i V^{(a, e, o)} \rightarrow i j V^{(a, e, o)}$ & + & - & + & + \\
\hline$a \rightarrow e /\left\{{ }^{i}{ }_{u}\right\}(\mathrm{C})_{-}$ & + & + & + & + \\
\hline Erak.: oneik (pl.) & + & 1 & - & + \\
\hline Art.: -atan & + & 1 & + & + \\
\hline Gen.: -an (sg.) & + & - & + & + \\
\hline Mug. adl.: -giño & + & 1 & + & + \\
\hline $\begin{array}{l}\text { Gazt. - miento > eusk. } \\
\text {-mi(e) ntu }\end{array}$ & + & - & + & + \\
\hline "edun: -de (pl.) & + & 1 & + & + \\
\hline "edun: euan > euen & + & 1 & + & + \\
\hline Pl. pleonas. $-e+-e>-i e$ & + & 1 & - & + \\
\hline Eduki: -au- >-eu- & - & 1 & - & + \\
\hline
\end{tabular}

Koadroa aztertuta, galdetegiko hizkera batago dator Sarriaren hizkera-eredu «herrikoia»-rekin, Orozko zein Aiara aldeko testuekin baino. Hala kuantitatiboki nola kualitatiboki hurbilago daude bateko eta besteko hizkerak: euskara bera ez bazen, oso hurrekoa izan behar zuen. Besteak beste, "edun-en adizkietako - de pluralgileak bermatzen du testua Bizkai sartaldekoa dela, eta erakusle singularren eta pluralen bereizketa morfologikoak, -atan erakusle gramatikalizatuak, -mintu aldaerak eta euan > enen asimilazioak Bizkaiko hego-sartaldera begira jartzen gaituzte. Bada, hego-sartalde horretan Nerbioi ibarraren iparraldeko hizkeran besterik ez dira sistematizatu, aldaera zaharragoei eutsi dieten hizkeren aurka (Txorierri, Galdakao, Arratia, Zeberio,

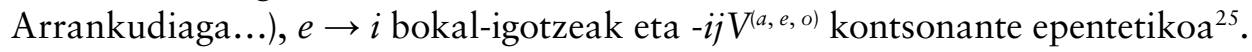

Hegoalderagoko testuei dagokienez, Orozkoko 1739ko otoitzen laburtasunak hainbat hutsune eragiten ditu konparazioan eta, gainera, aintzat hartu behar da kasu honetan otoitzak zaharragoak direla. Nolanahi ere den, otoitzetako eta galdetegiko hizkera ez dira bat eta bera: egia da morfologian aldaera batzuek lotzen dituztela hizkera bata eta bestea, baina gutxienez XVIII. mendearen amaieraz geroztik Nerbioi ibarraren iparraldeko euskararen bereizgarri izan diren ezaugarri fonologiko batzuek etena irudikatzen dute: Orozkoko otoitzetan $e$. $a$ hiatoa gorde den arren, Zolloko galdetegian $e \rightarrow i$ igoera agertzen da; gainera, Orozkoko euskara garaikidean igoera hori testuinguru jakin

24 Testuinguru jakin batzuetan.

25 Aurrekoez landara, sailkapen-lanean bazter utzi ditugu beheko bokalaren asimilazioa, muga-adlatiboko - giño eta genitibo singularreko - an aldaerak, eta adizkietako $-e+e>-i e$ bilakabidea; izan ere, hedadura ñabarreko edo lausoko bilakabideak dira, eta ikuspegi eta erabaki okerrak hartu eragin dezakete. 
batean besterik ez da gertatu (/u/ eta /i/ kontsonanteen ondotik: kinpullie, baina andrea), Basauri, Arrigorriaga edo Bilboko (eta Zolloko) auzoetako sistematikotasunetik urrun. Orobat, dakigula, Orozkon ez da $-i j V^{(a, e, o)}$ erako epentesirik erabili, eta Nerbioi ibarraren iparraldean (eta Zollon) sistematikoa da.

Hegoaldetik begiratuta ere bertsua da emaitza: gutxienez XVIII. mendearen bigarren erdiaz geroztik Orozkoko eta hegoalderagoko (Ulibarri, 2008 eta 2015) hizkeren ezaugarri izan diren zenbait bilakabide fonologiko (uan > uen > uin, -io- >-(i)u-, -ie > -ei, -tuite aditz-izenetan...) ez dira ageri iparralderagoko testu eta hizkeretan, eta Zolloko galdetegian ere ez daude.

Dotrinazko sermoitegia mardularekin alderatuta, lehen begi-kolpean antzekotasunak ugariagoak direla ematen du: Zolloko galdetegitik erauzitako ezaugarri morfologikoetako sei agertzen dira Aiaraldeko testuan, baina ezberdintasunak ere badaude erakusleen bereizketa morfologikoan eta zenbait bilakabide fonologikotan. Orozkorekiko konparazioan gertatzen zen legez, Zolloko galdetegian eta Nerbioi ibarraren iparraldeko hizkeretan zabalago eta indartsuago daude bokal-igotzeak eta kontsonante epentetikoak. Halaber, Dotrinazko sermoitegia-k dakarren arkaismo-sorta interesgarriaren (bokal sudurkariak, jakin laguntzailea, -no atzizki denborazkoa, ablatiboaren eta prosekutiboaren bereizketa, -tzaite aditz-izena, "ezan-en adibideren bat...) arrastorik ez dago iparralderagoko XVIII. mende amaierako iturrietan; gainera, arestian aipatutako Orozko aldeko eta Nerbioi ibarrean gora hedatu gabeko berrikuntza esklusibo batzuk agertzen dira sermoitegian, hegoalderagoko eremu batekiko konbergentzia islatuz.

Aurrekoak esanda, ematen du testuko hizkera hurbilago dagoela Nerbioi ibarraren iparraldeko XVIII. mendearen amaierako hizkeratik, hegoalderagokoetatik baino; alegia, testuak Bilboko Nerbioi ibarreko eremu berritzaileko euskara islatzen duela.

Zolloko euskararen kokapenari dagokionez, puntu interesgarria da aurrekoa; izan ere, esana dugu Bilbo hegoaldeko eta Zolloko egungo hizkerak oso hurbil daudela, eta inguru hartako azken bizpahiru mendeetako dinamikak zein diren ikusita, pentsa genezake Zolloko galdetegia prestatu zen garaian antzekoa edo bera zela egoera; hots, lotura eta dinamika linguistiko bertsuen mende zeudela ordurako Bilboko, Nerbioi ibarraren iparraldeko eta Zolloko hiztunak. Hartara, eskribauak ez zukeen berebiziko ahaleginik egin beharko hizkuntza moldatzeko.

\section{HIZTEGIA}

Hurrengo orrialdeetan, lan honetan aurkeztutako azterketa linguistikoaren osagarri, Zolloko galdetegiko euskal pasarteko hitz guztiak biltzen dira. Zehazki, hiztegiaren sarrerak ematean forma osoagoen alde egin dugu, oro har, eta grafia egungo arauen arabera moldatu dugu: aintzat hartu ditugu Orotariko euskal hiztegi-ko sarrerak, baina hala ikuspegi diakronikotik nola dialektologikotik interesa izan dezaketen aldaerak zeuden legez utzi ditugu. Ozen ondoko txistukariak arazotsu dira frikariak 
eta afrikatuak bereizten ez diren testuetan, eta erdibidea hautatu dugu, ez baitugu argitzerik izan ozen ondoko txistukariak era batera edo bestera gauzatzen ziren: $\langle(t)\rangle$ ezarri dugu ozen ondotik, bi aukerak aintzat har daitezen.

Hiztegiaren antolakuntzari dagokionez, sarreraren edo lemaren ondoren hitzaren kategoria eman dugu, laburduraren bidez; halaber, halakoetan egin ohi den legez, beharrezkotzat jo dugunean esanahia adierazi dugu. Azkenik, lemen azpian testuko adibideak agertzen dira, jatorrizko grafian eta ondoren testuko zein orrialdetan agertzen diren zehaztuta.

A

abade $i z$.

abade $3 \mathrm{r}$

abuztu $i z$.

abustuan $3 \mathrm{v}$

adiskide $i z$.

adisquide $3 \mathrm{v}$

agindu $a d$.

aguindu $4 \mathrm{r}, 4 \mathrm{r}$

ahun $(\mathbf{t}) \mathbf{z} i z$.

auns $4 \mathrm{v}$

aitobe $i z$. aitaita

aitobec $4 \mathrm{r}$

ajustau $a d$. konpondu, adostu

ajustau $4 \mathrm{r}$

Andres iz. prop.

Andres 3r, 3v, 4r, Andresec 3r, 4r, Andresegas 4r, Andresen 4r, 4r, Andreseri $4 \mathrm{v}$

aprobetxamintu $i z$.

aprobechamintuen $3 \mathrm{v}$

Arbide iz. prop.

Arbide 4v, Arbidec 3r, 4v, Arbideco 3v, Arbidecoc 3v, 3v, Arbidegas 3r, Arbiden 4r

ardatz $i z$.

ardaspat $4 \mathrm{v}$

artikuladu $i z$. artikulu-multzo

articuladua $3 \mathrm{r}$

artino postp. arte

artiño $3 \mathrm{v}$

arto $i z$.

arto $4 \mathrm{r}$, artoac $4 \mathrm{r}$

artuben $i z$. kreditu, hartzeko edo hartu

beharreko zenbateko artuben $3 \mathrm{v}$

asko zenbtz. zehaztgb.

asco $3 \mathrm{v}$

aurre $i z$.

aurrean $3 \mathrm{r}$, aurreti $4 \mathrm{v}$, aurretic $4 \mathrm{v}$

aurtengo $i z l a g$.

aurtengo $3 \mathrm{v}$

auzi $i z$.

ausi $4 r$, ausia $3 r$, ausiau 3r, ausiyatan $4 \mathrm{r}$

auzo $i z$. auzoko, bizilagun

ausoac $3 r, 3 r$

azienda $i z$. abere, abere-multzo

acienda $4 r$, hacienden $4 r$

azkero postp.

-az gero

urten asquero $4 r$, yl asquero $4 r$

\section{B}

bada lok.

bada $4 \mathrm{v}$

baga postp. gabe $\rightarrow$ bagarik baga $3 \mathrm{v}$

bagarik postp. gabe $\rightarrow$ baga bagaric $4 \mathrm{r}, 4 \mathrm{v}, 4 \mathrm{v}$

baino junt. bayño $4 \mathrm{v}$

baita junt. $3 \mathrm{r}, 3 \mathrm{v}, 4 \mathrm{v}$

balia(d)u ad. balietaco $4 \mathrm{v}$

balio $a d$. baliatu, erabili balio eta saldu eudela $4 \mathrm{v}$

baso $i z$.

basoetan $3 \mathrm{v}$ 
bat zenbtz. zehazt.

ardaspat $4 \mathrm{v}$, bat $3 \mathrm{v}, 3 \mathrm{v}, 3 \mathrm{v} 4 \mathrm{r}, 4 \mathrm{r}, 4 \mathrm{r}$, $4 \mathrm{r} 4 \mathrm{v}$, bategan $3 \mathrm{v}$, batera $3 \mathrm{v}$

bederatzi zenbtz. zehazt. vederazi $4 \mathrm{v}$

behi $i z$. bey $4 \mathrm{r}$

bera izord. bera $3 \mathrm{v}$, berari $3 \mathrm{r}$

bere izord.

bere $4 v$, bere $3 r, 3 r, 3 r, 3 v, 3 v, 3 v, 4 r$, $4 \mathrm{r}, 4 \mathrm{r}, 4 \mathrm{r}, 4 \mathrm{r}, 4 \mathrm{r}, 4 \mathrm{v}$, bereac $4 \mathrm{v}$

beste izlag. beste $3 \mathrm{r}, 3 \mathrm{r}, 3 \mathrm{v}, 3 \mathrm{v}$

bi zenbtz. zehazt. bi $3 \mathrm{v}, 4 \mathrm{r}$, viac $3 \mathrm{r}$

bigarren $\mathrm{ord}$. bigarrenagas $3 \mathrm{v}$

bizi ad.

bisi 3v

\section{C}

Calahorra iz. prop.

Calaorra 3r, Calaorraco 3r

Calzada iz. prop.

Calzadaco 3r

cura $i z$. abade

cura $3 r$

\section{D}

de prep. (gazt.)

de $3 r, 3 r, 3 r, 3 r, 3 v, 4 r, 4 r, 4 r, 4 v, 4 v$, $4 \mathrm{v}, 4 \mathrm{v}$

deklarau ad.

declarasera $4 \mathrm{v}$

denpora $i z$.

demporan $3 \mathrm{v}$, denporan $4 \mathrm{v}$

dobloa $i z$. dobloi, diru-mota bat

dobloa $3 \mathrm{v}$

Dominga $i z$. prop.

Dominga 3r, 3r, 4r, Domingac 3v, 4v

Domingo iz. prop.

Domingo 3r, 3v, 3v, 4r, 4r, 4v, 4v, Domingoc 3v, 4r, 4r
Don iz. (gazt.)

don $3 \mathrm{r}, 3 \mathrm{v}$

donazino $i z$. emari, dohaintza

donaciño-gaiti $4 \mathrm{r}$

\section{E}

*edin ad. lag.

$\operatorname{din} 3 \mathrm{v}$

edo junt.

edo $4 \mathrm{r}, 4 \mathrm{v}$

eduki $a d$.

badauquie $4 r$, daucala $3 r, 4 r$, daucasala $3 r$, $4 r$, dauquela $4 v$, dauquesala $3 v$, eucala $3 v$, eucan $4 r$, euqui $4 v$

*edun $a d$. lag.

dauela $3 \mathrm{r}$, ditusanacas $3 \mathrm{r}$, ditus $4 \mathrm{v}$, eudela $4 v$, eudesela $4 v$, euen $4 r$, eula $3 \mathrm{r}, 3 \mathrm{v}$, situesala $4 \mathrm{v}$, situsala $3 \mathrm{v}$, situsanacas $4 \mathrm{r}$, situsela $3 \mathrm{v}$, situsela $4 \mathrm{v}$, ynportateuan $3 \mathrm{v}$

*edutsi ad. lag.

deusen $3 r$, eusasan $4 r$, e[u]sela $4 r$, eusen $4 r$

egin

1 ad.

eguin $3 r, 3 r, 3 v, 4 r, 4 r$, eguiteco $3 r$

2 ad. lag.

daiensat $3 \mathrm{r}$

egon ad.

dagosanac 3r, dagosen 3r, egon 4r

eliza $i z$.

elesa $3 \mathrm{v}$

elizate $i z$.

elesate $3 r$

emazte $i z$.

emastec $4 v$, emaste $3 v, 4 v$, emastec $4 r$ emon $a d$.

emon $4 \mathrm{v}$, emonic $4 \mathrm{r}$

en(t)zun $a d$.

en(t)zutea eduki zerbaiten berri izan

ensutia badauquie $4 \mathrm{r}$

erdi $i z$.

erdiac 3v, erdiya $4 r$

erein $a d$.

erein $4 \mathrm{r}$ 
ereite $i z$. ereintza

ereitietan $4 \mathrm{r}$

eroan $a d$.

eroan $3 \mathrm{r}$

erosi $a d$.

erosi $4 \mathrm{r}$

errelazino $i z$. kontaketa, kontakizun errelaciñoa $3 r$

errezibidu $a d$. jaso

errezibidu $3 \mathrm{r}, 4 \mathrm{v}$

erropa $i z$.

erropac $3 r$

esan $a d$.

esan $3 \mathrm{v}, 3 \mathrm{v}$

estimazino $i z$. aurreikuspen, zenbates-

pen

estimasiño $3 \mathrm{v}$

eta junt.

eta $3 r, 3 r, 3 r, 3 r, 3 v, 3 v, 3 v, 3 v, 3 v, 3 v$, $4 \mathrm{r}, 4 \mathrm{r}, 4 \mathrm{r}, 4 \mathrm{r}, 4 \mathrm{r}, 4 \mathrm{r}, 4 \mathrm{r}, 4 \mathrm{v}, 4 \mathrm{v}, 4 \mathrm{v}, 4 \mathrm{v}$, $4 \mathrm{v}, 4 \mathrm{v}$, ta $4 \mathrm{r}, 4 \mathrm{v}$

Etxatxu iz. prop.

Echachuco 3r, 3v, 4r

etxe $i z$.

echea 3r, 3v, echean 3v

etxi ad. utzi $\rightarrow$ itxi

echi $3 \mathrm{v}, 4 \mathrm{r}$, echiyac $4 \mathrm{v}$

eurak izord.

eurai $4 r$

exkomunino $i z$.

excomuniño $4 \mathrm{v}$

ez $a d b$.

es $3 r$

ezkondu $a d$.

escondu $3 \mathrm{r}, 3 \mathrm{v}$

\section{F}

fakultede $i z$. eskubide, ahalmen facultederic $4 \mathrm{v}$

\section{G}

gabi $i z$. errementarien lanabesa

gabi $4 \mathrm{v}$

gastu $i z$. gastua $4 \mathrm{r}$

gauza $i z$.

gausaric $3 \mathrm{r}$

gero $a d b$.

guero $3 \mathrm{v}$

gobernau $a d$.

gobernau $4 \mathrm{r}$

Goikolanda iz. prop.

Goicolanda 3v

Goiri iz. prop.

Goiri 4r, Goirigas 4r

gorde $a d$.

gorderic $3 \mathrm{r}$

gozadu $i z$. gozatu

gosadu $3 \mathrm{v}$, gozetan $4 \mathrm{r}$

gozemen $i z$. onura, probetxu

gozemenenac $4 \mathrm{v}$

guraso $i z$.

gurasoac $4 \mathrm{r}$

guzti zenbtz. orok.

gustien $4 \mathrm{r}$, gustiya $4 \mathrm{v}$, gustiyac $4 \mathrm{v}$, gustiac $3 r$, $4 r$, gustiai $3 r$, gustioc $3 v$

\section{$\mathrm{H}$}

harik

aric ona $3 \mathrm{r}$

halan $a d b$.

alan $4 \mathrm{v}$

hamazor(t)zi zenbtz. zehazt. amasorsi $4 \mathrm{v}$

hamazor $(\mathbf{t})$ zigarren zenb. ord. amasorcigarreneguino $3 \mathrm{v}$

handi $i z o n d$.

andicoac $3 \mathrm{v}$

hau

1 erak.

au $3 r$, onegas $3 \mathrm{v}$, onen $4 r$, oneri $4 r$, $4 \mathrm{r}$, onetaraco $4 \mathrm{v}$, onetaco $3 \mathrm{r}, 3 \mathrm{r}, 3 \mathrm{r}$, $3 \mathrm{v}$

honez ostean honen ondoren

ones ostean $4 \mathrm{r}$

2 art. hur.

ausiau 3r

hemeko adj. hemengo

emeco $4 \mathrm{v}$ 
herri $i z$.

erri $3 \mathrm{r}$

hil ad.

$\mathrm{yl} 4 \mathrm{r}$, ylgo $3 \mathrm{v}$

hona $a d b$.

ona $3 \mathrm{r}$

honeik erak. hauek

onei[c] 3v, oneic $3 \mathrm{r}, 4 \mathrm{r}, 4 \mathrm{v}, 4 \mathrm{v}, 4 \mathrm{v}$

I

ifini ad. ipini

yfiniric $3 r$

igualmente $a d b$. (gazt.) halaber

ygualmente $4 \mathrm{v}$

inbentario $i z$.

ynbe[n]tarioric $3 \mathrm{v}$

informazino $i z$.

ynformaciñoetara $3 \mathrm{r}$

inoizko izlag. inoizko

iñosco $4 \mathrm{v}$

inporta(tu) ad. balio izan

ynportateuan $3 \mathrm{v}$

Ipiñazar $i z$. prop.

Ypiñazarrec 4r, 4v, Ypiñasarrec 4v

irautsi $a d$. hitz egin, esan

dirause $3 \mathrm{r}$

Isusi $i z$. prop.

Ysusicogan 3v

Iturriaga $i z$. prop.

Yturriaga-gan $3 \mathrm{v}$

itxi ad. utzi $\rightarrow$ etxi

ychiac $4 \mathrm{v}$

izan

$1 \mathrm{ad}$.

balisela $4 \mathrm{v}$, dira $4 \mathrm{v}$, dirian $3 \mathrm{r}$, isan $3 \mathrm{v}$, san $4 \mathrm{r}$

2 ad. lag.

dala $3 r$, dan $3 v, 3 v, 3 v, 3 v$, diriela $4 r$, iacana $3 r$, sala $4 r, 4 r$, san $3 v, 3 v, 4 r$ sanean $3 r$, siriala $4 r$, siriela $4 r$, yacasala $4 \mathrm{r}$, yaque $4 \mathrm{v}$ jakin ad.

badaquie $3 \mathrm{r}, 3 \mathrm{v}, 3 \mathrm{v}, 3 \mathrm{v}, 3 \mathrm{v}, 4 \mathrm{r}, 4 \mathrm{r}, 4 \mathrm{r}$, $4 \mathrm{r}, 4 \mathrm{r}, 4 \mathrm{v}, 4 \mathrm{v}$, daquianay $4 \mathrm{v}$, daquien $4 \mathrm{v}$, jaquin $3 \mathrm{v}$

jaun $i z$.

jaun $3 \mathrm{r}$, jaunac $4 \mathrm{v}$, jaunen $3 \mathrm{r}, 4 \mathrm{v}$

jeneral $i z o n d$.

jeneralac $3 \mathrm{r}$

Joseph iz. prop.

Joseph $3 \mathrm{r}$

Josepha iz. prop.

Josepha 4r

Juan $i z$. prop.

Juan $4 \mathrm{r}$

K

kaxa $i z$.

cashacas $3 \mathrm{v}$, cashetan $3 \mathrm{r}$

konponidu ad. osatu

componietan $4 \mathrm{r}$, conponiduric $3 \mathrm{v}$

kontratu $i z$.

contratuan $3 \mathrm{r}$

korrejidore $i z$.

corregidoren $3 \mathrm{r}$

kostu $i z$.

-en kostura -en kargura, lepora

onen costura $4 \mathrm{r}$

kunplidu izond. bete

cumpliduec $3 \mathrm{v}$

L

laugarren ord.

laugarren $4 \mathrm{r}$

lauoineko $i z$. txerri

lauoñeco $4 \mathrm{r}$

legez postp.

leges $4 \mathrm{v}$

leku $i z$.

lecuric $4 \mathrm{v}$

libradu $a d . \rightarrow$ librau

libradu $4 \mathrm{v}$

librau $a d . \rightarrow$ libradu

libreu $3 r$ 
lo mismo lok. (gazt.) halaber, gauza bera

lo mismo $4 \mathrm{v}$

luze $i z o n d$.

luse $4 \mathrm{r}$

M

maisu $i z$.

maisu $4 \mathrm{v}$

mando $i z$.

mando $4 \mathrm{v}$, mandoagas $4 \mathrm{v}$

Manuela $i z$. prop.

Manuela 3v

matrimoñiatu $i z$.

matrimoñiatura $3 \mathrm{r}$

Melchor iz. prop.

Melchor 3v

motibu $i z$. arrazoi

motibu $3 \mathrm{v}$

\section{$\mathbf{N}$}

nagusi $i z o n d$. nagusi

nagusian $4 \mathrm{v}$

$\mathrm{O}$

obispadu $i z$.

obispadu $3 r$

obispo $i z$.

obispo $3 \mathrm{r}$

obligazio $i z$.

obligacio $4 \mathrm{v}$

ohe $i z$.

oiacas $3 \mathrm{v}$

ondasun $i z$.

ondasun $3 \mathrm{v}, 3 \mathrm{v}$

ondo $a d b$.

ondo $3 \mathrm{v}, 4 \mathrm{r}$

osoan $a d b$. guztiz, osorik

osoan $3 \mathrm{v}$

ostean $a d b$.

ostean $4 \mathrm{r}$

Otheo $i z$. prop.
Otheo $3 \mathrm{r}$

Otxoa iz. prop.

Ochoa 3v

\section{$\mathbf{P}$}

pago $i z$.

pago $4 \mathrm{v}$

parte $i z$.

partea $4 \mathrm{r}, 4 \mathrm{v}$

-en partez

obispo jaunen partes 3r, aguindu eusasan partes 4r, Andresen partes $4 r$

Peragarrena $i z$. prop.

Peragarrena $3 \mathrm{v}$

podere $i z$.

poderean $3 \mathrm{v}, 4 \mathrm{r}, 4 \mathrm{r}$

prebenidu $a d$. ohartarazi

prebenietan $4 \mathrm{v}$

pregunta $i z$. galdera

pregunta $3 \mathrm{r}, 3 \mathrm{r}, 4 \mathrm{v}$

presentau $a d$.

presentau $3 \mathrm{r}$

probisore $i z$.

provisore $3 \mathrm{r}, 4 \mathrm{v}$

$\mathbf{R}$

Ruiz iz. prop.

Ruiz 3r

\section{S}

Salazar iz. prop.

Salazarrecoc 3r, Salazarregas 3r

saldu $a d$.

saldu $4 \mathrm{v}, 4 \mathrm{v}, 4 \mathrm{v}$

sei zenbtz. zehazt.

sei $3 \mathrm{v}$

seme $i z$.

semeari $4 \mathrm{r}$

senar $i z$.

senarra $4 r$, senarrag[a]s $4 r$ 


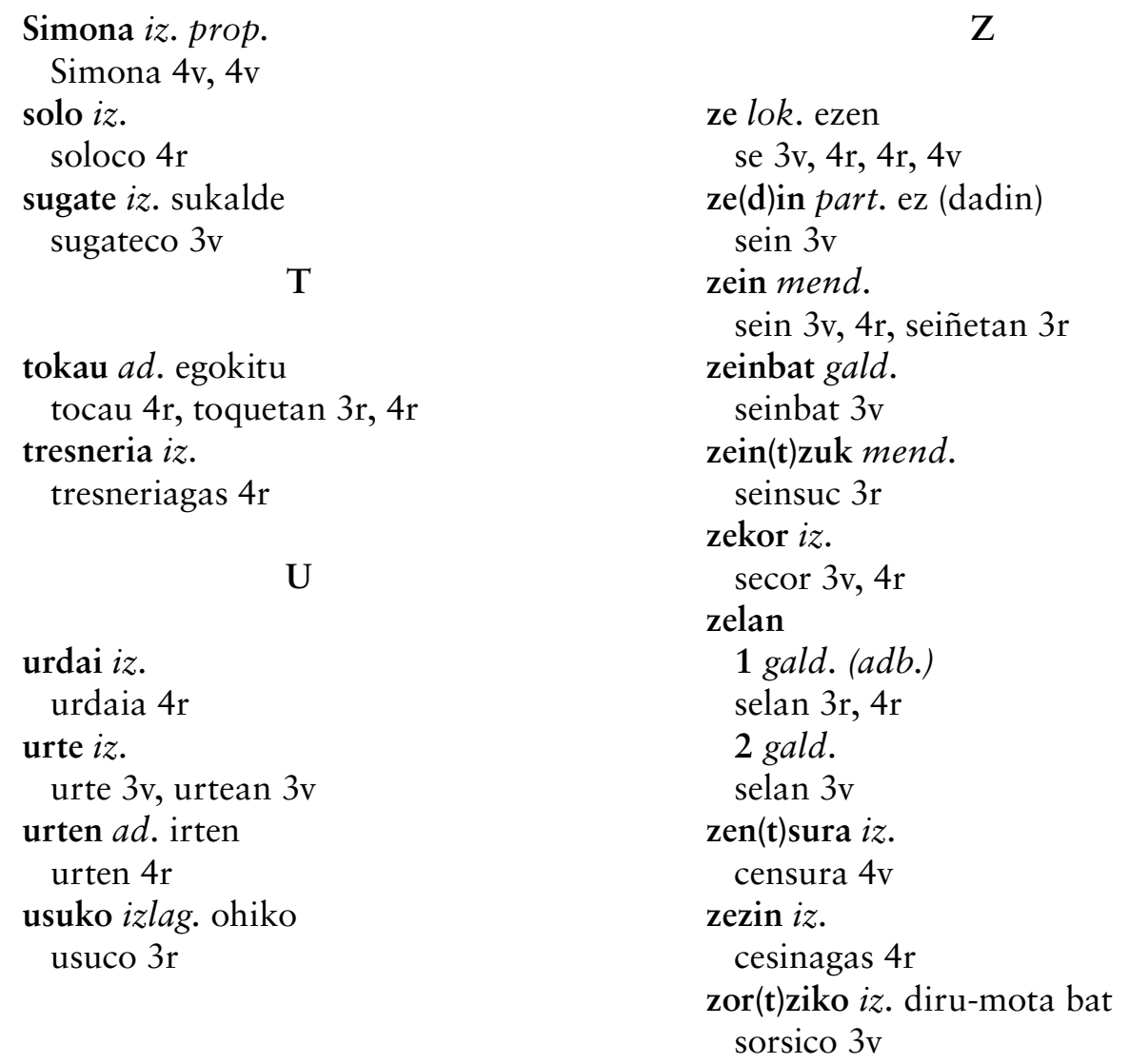

\section{ERREFERENTZIAK}

\subsection{Iturriak}

9.1.1. Bizkaiko Foru Agiritegi Historikoa (AHFB/BFAH)

9.1.1.1. Atal judiziala, korrejimentuaren funtsa

JCR0535/003 (1785), JCR0489/009 (1770), JCR1615/008 (1766), JCR2664/005 (1764), JCR0192/004 (1754), JCR0985/009 (1753), JCR0881/022 (1746), JCR0532/005 (1737), JCR0695/010 (1767), JCR3654/017 (1783).

\subsubsection{Bizkaiko Administrazio Atala}

AJ00451/003 (1800-1858) [Gernikako Batzar Nagusien Funtsa. Esp.: erreg. 016, 02 dok., 02 zk.], AJ00487/003 (1770-1779), AJ01639/070 (1770), AJ0434/001 (1858), AJ0441/001, AJ0442/001, AJ0443/001, AJ0444/001 (1870-1877) [Bizkaiko Batzar Nagusien Aktak], AJ00034/032 (1767), AJ00012/035 (1779), AJ00012/042 (1779), AJ00012/043 (1779), AJ00012/046 (1780), AJ00012/047 (1780), AJ00012/48 (1780) [idazkaria, José], AJ0859/052 (1782) [idazkariordea, Antonio]. 


\subsubsection{Udal Atala}

9.1.1.3.1. Bilboko Udal Artxibo Historikoa

Bilbao Antigua 0273/001/025 (1767-1768), Bilbao Antigua 0273/001/037 (1770)

[Irizpenak, José], Bilbao Antigua 0445/001/017 (1770) [Irizpenak, Antonio].

\subsection{Atal instituzionala. Kontsulatuko funtsa}

Consulado 0572/001/103 (1766), Consulado 0572/001/145 (1770), Consulado 0278/001/003 (1772), Consulado 0278/001/006 (1779) [Irizpenak, Antonio].

\subsubsection{Bizkaiko Artxibo Historiko Probintziala (BAHP/AHPB)}

Atal notariala. Dokumentuaren signatura: José de Aranzazugoitia 2627 (1770. urtea).

\subsubsection{Bizkaiko Elizaren Histori Arkibua (AHEB/BEHA)}

Erregistro sakramentalak: Bilboko eta Artea-Elexabeitiako (Arteaga) parrokiak, eta Zolloko San Martin elizatekoa.

\subsection{Azterlanak}

Altuna, F. (1995). Acto contriciocoa eriotzaco orduracò: Garcia de Albeniz araiarraren araberazko eskuizkribua (1778). ASJU, 29(1), 83-132.

Arnal, M. (2000). Cambios grafemáticos en textos notariales aragoneses del siglo XVIII, a la luz de las reformas ortográficas de la RAE. Archivo de filología aragonesa, 56, 117-136.

Artiñano, A. (1985 [1885]). El Señorío de Bizcaya, histórico y foral. Bilbo: Editorial Amigos del Libro Vasco.

Arretxe, J. (1994). Basauriko euskara. Basauri: Basauriko Udala.

Azkue, R. M. (1925). Morfología vasca. Bilbo: Euskaltzaindia.

Bell, A. (1984). Language style as audience design. Language in Society, 13, 145 204.

Castaños, F. (1957). El genitivo en vizcaíno antiguo. BAP, 13, 60-69.

Cifuentes, J. M. (1993). Estudio histórico-artístico de Ugao-Miraballes. Bilbo: Bizkaiko Foru Aldundia.

De Rijk, R. P. G. (1970). Vowel interaction in Bizcayan Basque. Fontes Linguae Vasconum, 2, 149-67.

Díaz de Durana, J. R. (arg.). (2006). Investigaciones sobre historia medieval del País Vasco (1965-2005) del profesor José Ángel García de Cortázar y Ruiz de Aguirre. Bilbo: UPV/EHU.

Elorriaga, C. (1995). Arakaldo, Arrankudiaga-Zollo. Estudio histórico y artístico. Bilbo: Bizkaiko Foru Aldundia.

Esteban, J. (2018). Discursos civilizadores. Escritores, lectores y lecturas de textos en euskera (c. 1767 - c. 1888). Madril: Sílex.

Etxazarra, A. (2012). Bizkai sartaldeko XIX. mendeko zenbait dotrinaren azterketa (master-tesi argitaragabea). UPV/EHU, Vitoria-Gasteiz.

Etxebarria, J. M. (1991). Zeberio haraneko euskararen azterketa etno-linguistikoa. Zornotza: Ibaizabal. 
Gaminde, I. (2002). Gaurko Bilboko euskararen ezaugarriak. In A. Arejita, A. Elejabeitia, C. Isasi \& J. Otaegi (arg.), Bilboren 700. urteurrena. Hizkuntza gunea (391-414. or.). Bilbo: Deustuko Unibertsitatea.

Gaminde, I. (2007). Bizkaian zehar. Euskararen ikuspegi orokorra. Bilbo: Mendebalde Kultura Alkartea.

García de Cortázar, J. A., Arízaga, B., Ríos, M. L. \& Del Val, M. I. (1985). Bizkaia en la Edad Media. Evolución, demografía, economía social y política de la comunidad vizcaina medieval. Donostia: Haranburu.

Himmelmann, N. P. (2001). "Articles". In M. Haspelmath, E. König, W. Oesterreicher \& W. Raible (arg.), Language Typology and Language Universals. An International Handbook (831-841. or.). Berlin \& New York: Walter de Gruyter.

Igartua, I. \& Santazilia, E. (2013). Instrumentalaz gogoratuz, instrumentuaz haratago. Kasuaren izaera tipologian eta euskararen bilakabidea. In R. Gómez, J. Gorrochategui, J. A. Lakarra \& C. Mounole (arg.), Koldo Mitxelena Katedraren III. Biltzarra (229-244. or.). Vitoria-Gasteiz: UPV/EHU.

Irigoien, A. (1958). Curiosidades y observaciones sobre el dialecto vizcaíno literario. Euskera, 3, 105-132.

Isasi, C., Iribar, A. \& Túrrez, I. (2012). Seseo vasco. Nuevos aportes. In B. Camus \& S. Gómez Seibane (arg.), El castellano del País Vasco (173-190. or.). Bilbo: UPV/EHU.

Iturriza, J. R. (1884). Historia general de Vizcaya... (F. Fitaren edizioa). Bartzelona: Subirana.

Iturriza, J. R. \& Azkarraga, M. (1985 [1885]). Historia general de Vizcaya... Bilbo: Editorial Amigos del Libro Vasco.

Iturriza, J. R. \& Rodríguez, A. (1967). Historia general de Vizcaya... Bilbo: Librería Arturo.

Krajewska, D. (2017). Euskararen sintaxi diakronikorantz: egitura konplexuak (doktorego-tesia). UPV/EHU, Vitoria-Gasteiz.

Krajewska, D. (2019). Erlazio-atzizkia eta hitz-ordenaren aldaketa. Fontes Linguae Vasconum, 127, 85-122.

Labayru, E. J. (1971). Historia general del señorío de Bizcaya. Bilbo: La Gran Enciclopedia Vasca.

Lakarra, J. A. (1984). Bizkaiera zaharreko ablatiboaz. ASJU, 18(1), 161-193.

Lakarra, J. A. (1985). Literatur gipuzkerarantz: Larramendiren Azkoitiko sermoia (1737). ASJU, 19(1), 237-281.

Lakarra, J. A. (1986). Bizkaiera zaharra euskalkien artean. ASJU, 20(3), 639-682.

Lakarra, J. A. (2011). Erro monosilabikoaren teoria eta aitzineuskararen berreraiketa: zenbait alderdi eta ondorio. Fontes Linguae Vasconum, 113, 5-114.

Lakarra, J. A. (2013). Euskararen historiaurrearen berreraiketa sakonagorako: forma kanonikoa, tipologia holistikoa, kronologia eta gramatikalizazioa. In R. Gómez, J. Gorrochategui, J. A. Lakarra eta C. Mounole (arg.), Koldo Mitxelena Katedraren III. Biltzarra (275-234. or.). Vitoria-Gasteiz: UPV/EHU.

Madariaga, J. (2014). Sociedad y lengua vasca en los siglos XVII y XVIII. Bilbo: Euskaltzaindia. 
Maiora, F. (2011). Reino de Navarra. Euskera: injurias, coplas, frases. Idazlea editore.

Maiora, F. (2018). Reino de Navarra. Euskera, lengua inteligible. Causas del retroceso, injurias, coplas... Idazlea editore.

Marcet, V. J. (2007). El lenguaje de los documentos notariales leoneses. In M. Fernández \& A. López (arg.), Cuatrocientos años de la lengua del Quijote: estudios de historiografía e historia de la lengua española (347-458. or.). Sevilla: Sevillako Unibertsitatea.

Martínez-Areta, M. (2013). Demonstratives and Personal Pronouns. In M. MartínezAreta (arg.), Basque and Proto-Basque. Language-Internal and Typological Approaches to Linguistic Reconstruction (283-321. or.). Frankfurt am Main: Peter Lang.

McIntosh, A., Samuels, M. L. \& Benskin, M. (1986). A Linguistic Atlas of Late Mediaeval English. Aberdeen: Aberdeen University Press.

Mitxelena, K. (1955). La doctrina cristiana de Betolaza (1596). Berrarg. in Obras completas XI, 187-204.

Mitxelena, K. (1961). Fonética histórica vasca. Berrarg. in Obras completas VI.

Mitxelena, K. (1981). Lengua común y dialectos vascos. Berrarg. in Obras completas VII, 517-543. or.

Monteano, P. (2017). El iceberg navarro. Euskera y castellano en la Navarra del siglo XVI. Iruñea: Pamiela.

Mounole, C. (2018). Le verbe basque ancien: étude philologique et diachronique. ASJU, $48(1 / 2), 1-506$.

Ramos, F. (1993). Monografía de la Anteiglesia de Arrigorriaga. Bilbo: Bizkaiko Foru Aldundia.

Ros, A. (2004). Bizkaierako subjuntivo zaharrak. Hegoaldeko testigantzak. Litterae vasconicae, 9, 233-248.

Salazar, B. (2001). Ugaoko euskara. Bilbo: Beta.

Santazilia, E., 2017, "Orye, lagunac. Euskara nafarraren aztarnak XVI. mendeko hiru sorginkeria auzibidetan”. RIEV, 62(2), 374-406.

Santazilia, E., 2018. Gora, gora, jendeac! Euskal testu berriak XVI. eta XVII. mendeetako justizia auzibide nafarretan. Euskera, 63(2/1), 419-460.

Santazilia, E., 2019. Ala ffede, bada! Euskal testu berri gehiago Nafarroako XVI. mendeko justizia auzibideetan. Uztaro, 108, 29-51.

Trask, L. (1995). On the history of the Non-Finite Verb Forms in Basque. In J. I. Hualde, J. A. Lakarra \& R. L. Trask (arg.), Towards a History of the Basque Language (207-234. or.). Amsterdam: John Benjamins.

Trebiño, I. (2001). Administrazio zibileko testu historikoak. Vitoria-Gasteiz: IVAP/ HAEE.

Trebiño, I. (2002). "Administrazio zibilean euskaraz sortutako dokumentazio historikoa: konklusioak eta agiri gehiago. Eleria, 9, 73-83.

Ulibarri, K. (2008). Orozkoko euskararen azterketa diakronikorantz hurbiltze bat. ASJU, 42(1), 191-207.

Ulibarri, K. (2009). Viva Jesus dotrinaren azterketa bibliografia materialen arabera. In R. Etxepare, R. Gómez, J. A. Lakarra (arg.), Beñat Oihartzabali gorazarre - Festschrift for Bernard Oyharçabal. ASJU, 43(1/2), 861-872. 
Ulibarri, K. (2010). Viva Jesús dotrina: edizioa eta azterketa. ASJU, 44(2), 41-154.

Ulibarri, K. (2015). Dotrinazko sermoitegia: galduriko hizkerak eta dialektologia historikoa (doktorego-tesi argitaragabea). UPV/EHU, Vitoria-Gasteiz.

Urgell, B. (1987). Esku-liburuaren grafi aldaketak (1801-1821). ASJU, 21(2), 357-387.

Urgell, B. (arg.). (2001). Fr. Pedro Antonio Añibarro. Geroko gero. Edizio kritikoa. Bilbo: Euskaltzaindia.

Urgell, B. (2006). Para la historia del sustantivo verbal en vasco. In J. A. Lakarra \& J. I. Hualde (arg.), Studies in Basque and Historical Linguistics in Memory of R. L. Trask. ASJU, 40(1/2), 921-948.

Urgell, B. (2018). Lehen Euskara Modernoa. In J. Gorrotxategi, I. Igartua \& J. A. Lakarra (arg.), Euskararen historia (549-657. or.). Vitoria-Gasteiz: Eusko Jaurlaritza.

Urrutia, A. (2003). Bizkaiko Batzar Nagusiak eta euskara: 1833-1877. Bilbo: Bizkaiko Batzar Nagusiak.

Urrutia, A. \& Lobera, A. (1995). Euskara, zuzenbidearen hizkera. Bilbo: Deustuko Unibertsitatea.

Yrizar, P. (2001). Memorias de un vascólogo: mis relaciones con lingüístas y colaboradores. Madril: Delegación en Corte.

Zabala, J. M. (1848). El verbo regular vascongado del dialecto vizcaino. Donostia: Ignacio Ramón Baroja.

Zuazo, K. (2014). Euskalkiak. Donostia: Elkar.

Zuazo, K. (2017). Mendebaleko euskara. Donostia: Elkar.

Zuloaga, E. (2010). Nerbioi ibarreko euskara XVIII. eta XIX. mendeetan (I): Bizente Sarriaren bizkaierazko sermoiak. ASJU, 44(2), 393-435.

Zuloaga, E. (2011a). Nerbioi ibarreko euskara XVIII. eta XIX. mendeetan (II): Juan Ignazio Astigarragaren sermoi-bilduma. ASJU, 45(1), 235-276.

Zuloaga, E. (2011b). Bizkaiko jauntxoen inguruko herri-literaturaz: Plentziako 1603ko hiru esaera zahar eta Refranes y sentencias-en jatorria, eta proposamen bat Arrasateko erreketaren kantuez. ASJU, 45(2), 53-69.

Zuloaga, E. (2013). Oharrak Nerbioi ibarreko euskara zaharraz eta Viva Jesus dotrinaren jatorriaz. In R. Gómez, J. Gorrochategui, J. A. Lakarra \& C. Mounole (arg.), Koldo Mitxelena Katedraren III. Biltzarra (593-610. or.). VitoriaGasteiz: UPV/EHU.

Zuloaga, E. (2017). Beheko bokalaren asimilazioaren historiarako: Mendebaleko datuak. Fontes Linguae Vasconum, 123, 157-199.

Zuloaga, E. (2015). Bizkaiko euskararen barne-egituraketaz: sartaldea eta sortaldea. Inprimategian-a.

Zuloaga, E. (2018). Iraganaren azterketak dialektologian osa ditzakeen hutsuneez. Inprimategian-b. 


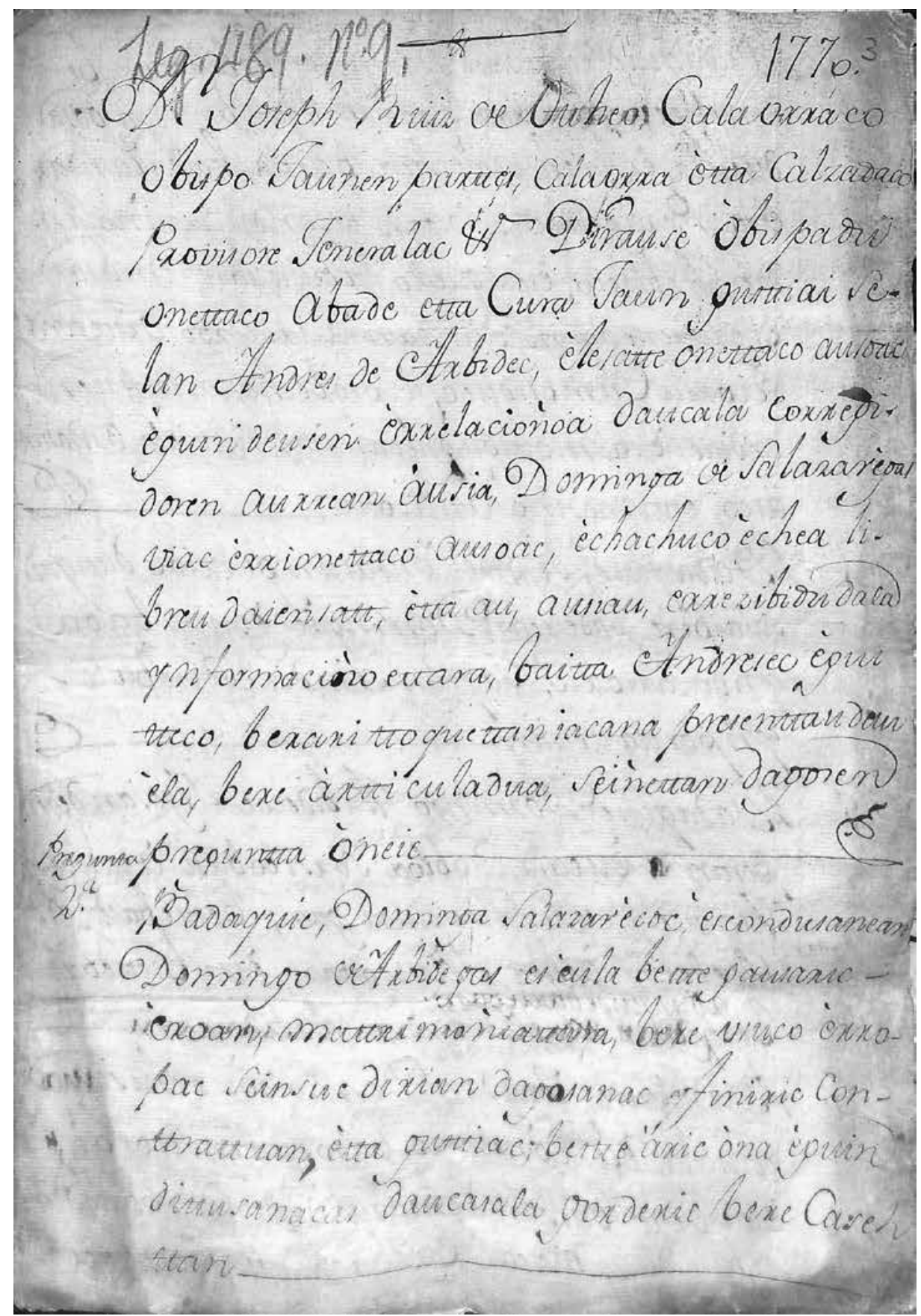

26 Bihoazkie mila esker eta bi Bizkaiko Foru Agiritegi Historikoko (BFAH) langileei, hemen argitaratzen diren irudiak digitalizatzeagatik eta lan honen eranskin gisa argitaratzeko aukera emateagatik. 


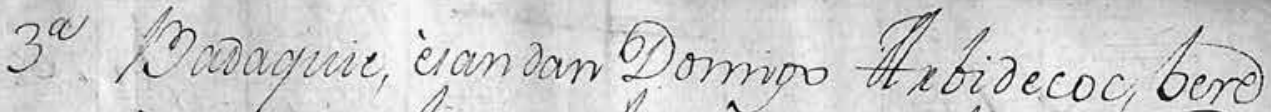

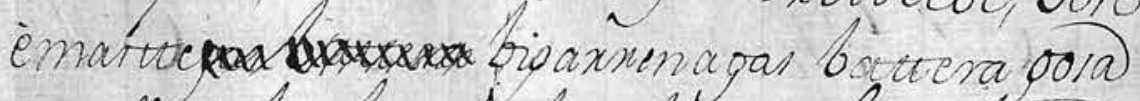
anenta, echachuco echea, bavwa, boicolaña). etra Oexapaxiena, orsan esconducintino An. ine, Antijeco, èra quexo Abirmuan amanox

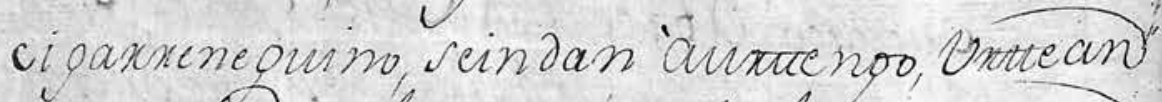
rivatie Cimolianec, ćórobechamintumen) exdiac, eua movibuionépar iran itumela Onamm àco, catimainizo ansicocuc

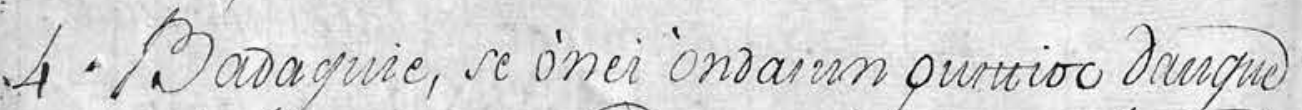

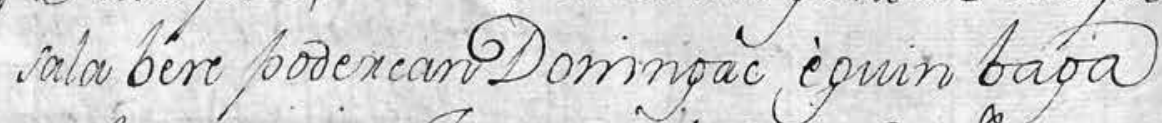

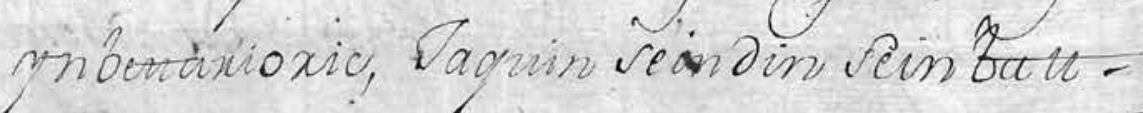

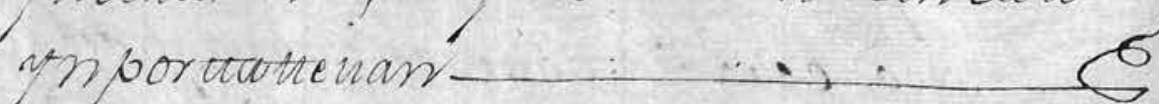

S. Wabadrie Domino Anoidecoc Whorandem boran incala, dobloa soxricobail ámuruben

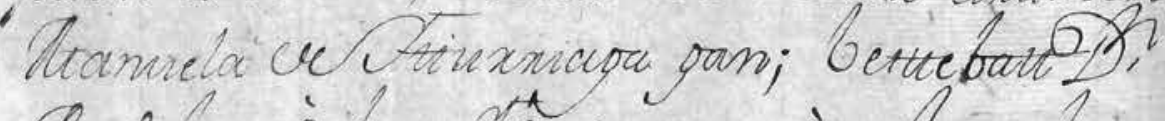

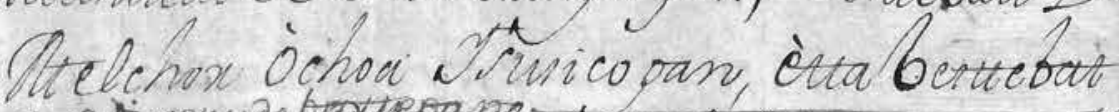

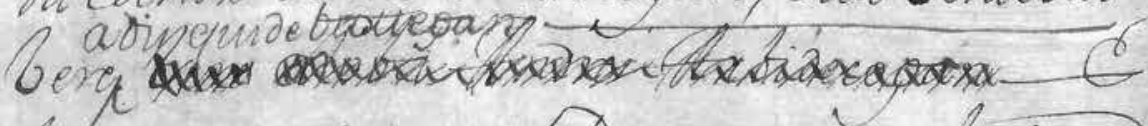

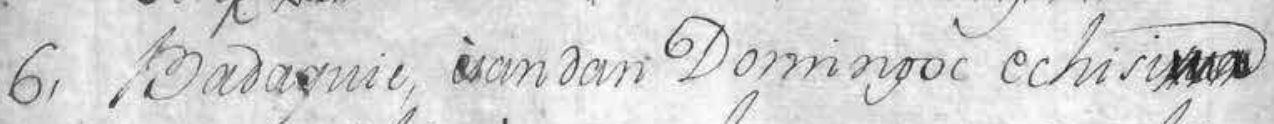
Ammala, eleia oneraco barogtan, secor ovi, ima bexa Givion echean; inso comboniduric Selan Jan, Diacar, Cashacai, erta. upatreco 


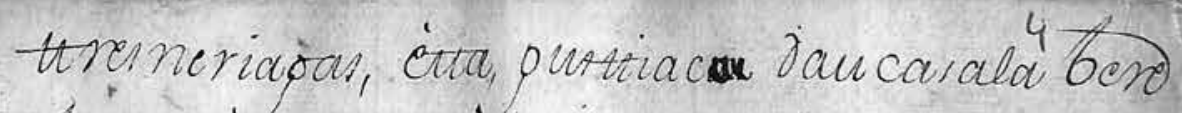
boderears

ooderear, $\rightarrow$

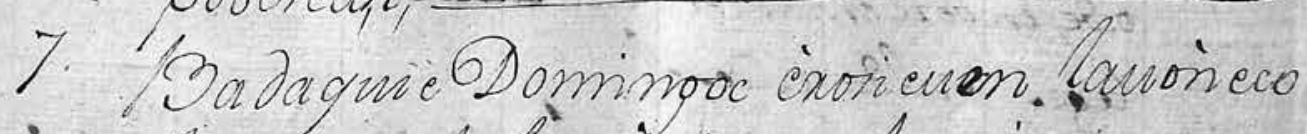
Gat, Saucala bene boverean bere ematrec CI

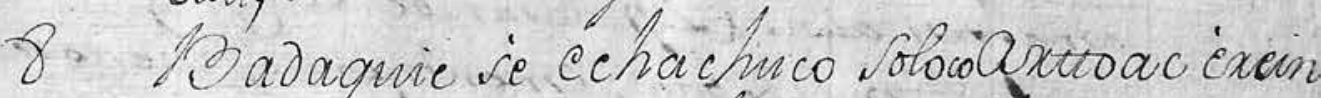
siniala Oominow. Htar quexp, fromen bur.

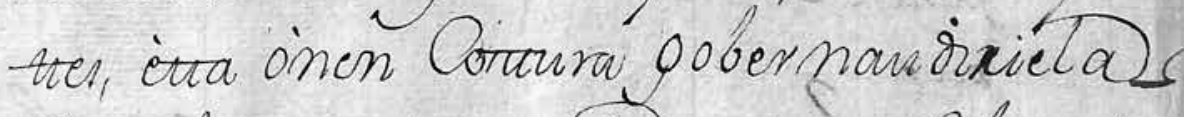

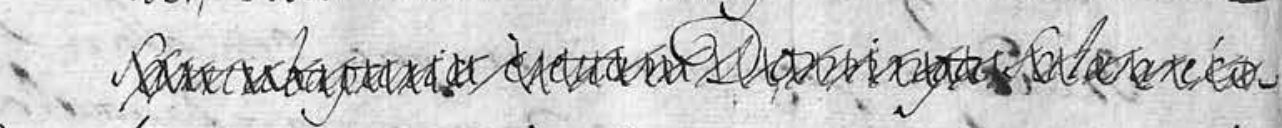

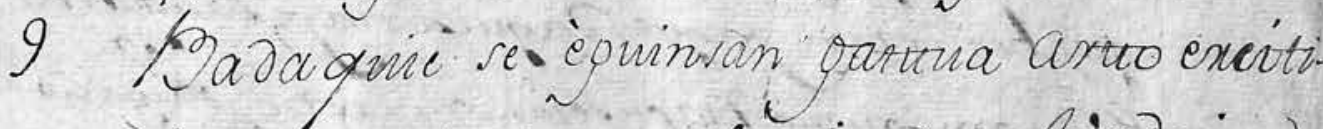
ittan, combonierianialá, saxdoria)

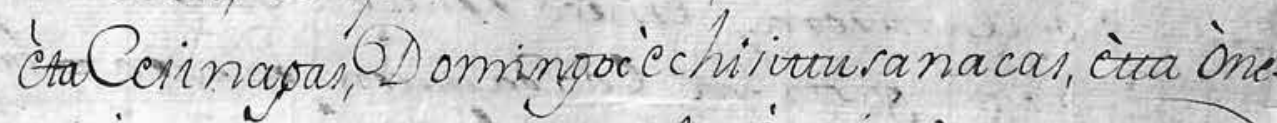
- ic, troquetan jacarala, áprimirucusasan bartié ftindri bere semeaxi.

10 Badaguie, Do en rutia badauquce relan Mroxusec encan auri Lurebaz Domingo achoriggar Iosepham Axbiden venaxiag sein ran oneý bexegun roage gugneuren Smaciono garti, eta unter arquepo au

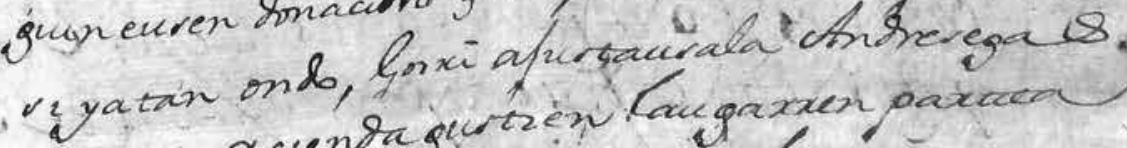
emanie acuensaguone? lacug

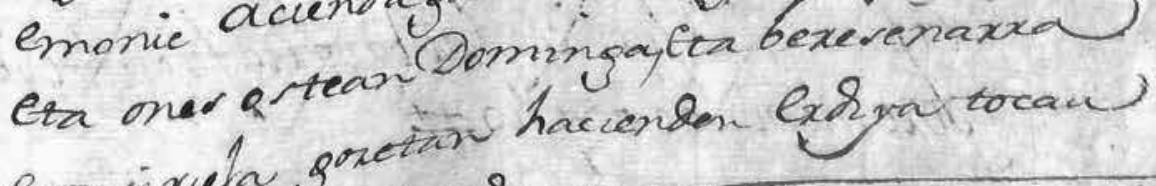
bupaxic enxai

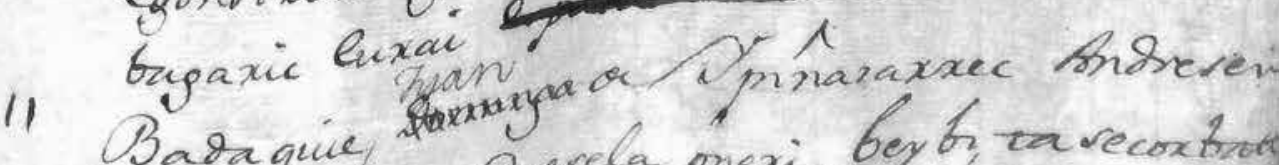

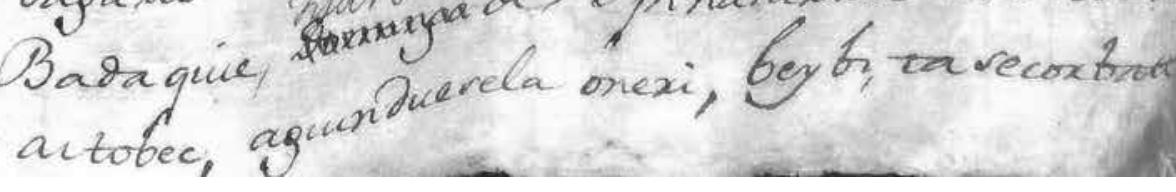


Eneko Zuloaga SAn Román, José Alfonso AnTEQUera CHÁveZ

150

$\therefore$ eta oncic Mereutidu vinusula Somngo canta brse, tabexc emavtec exa bexeac balceta leger valbre cuderela.

12 Baragui Comsmo baho eta valdre cudela

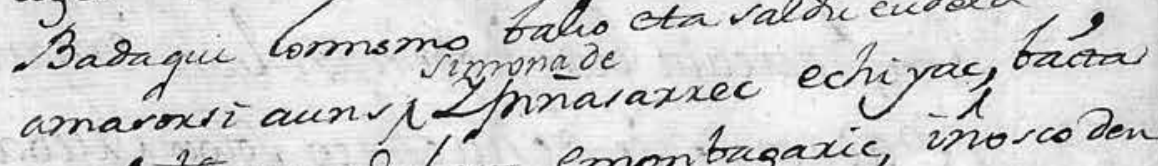
yualm mando bac, emontragaxic, iñorco den porain Angrevexi lecuxic balezaco, mandoa, ban-

Onevira pregunaa gurn yas en alan prebeniezan yaque, Daguia naj, Dauguela escomuniño Rapureian auxienc, oblyacióDeclararera, emeco Mavu Daunen aw xxer gura ja edosaguen paxicea = ba sa onctaraco Lbrahe htue Cenvura orecio Pxo virove Vunace

$\therefore$

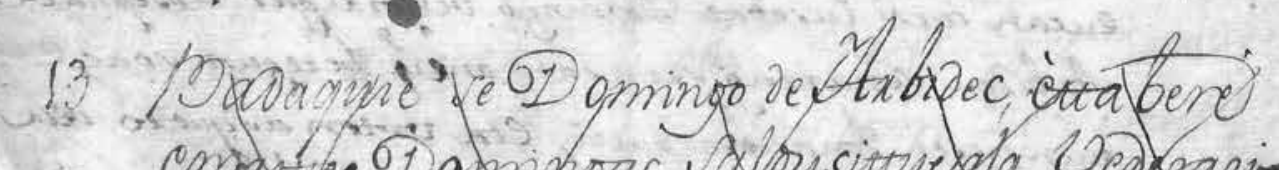

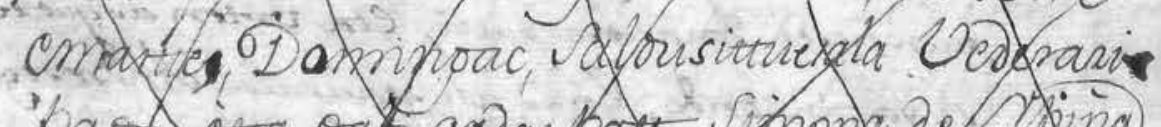

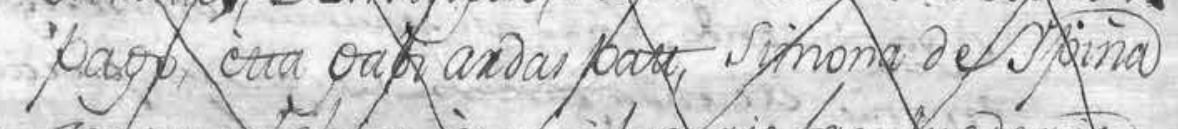

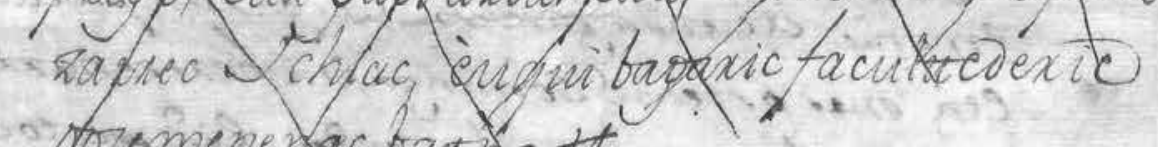
Doremenen tar no \#

504

Fontes Linguae Vasconum (FLV), 128, julio-diciembre, 2019, 455-504

ISSN: 0046-435X ISSN-e: 2530-5832

0000 